\title{
Structure and transport of the Iceland Scotland Overflow plume along the Reykjanes Ridge in the Iceland Basin
}

\author{
Torsten Kanzow ${ }^{\mathrm{a}, \mathrm{b}, *}$, Walter Zenk ${ }^{\mathrm{a}}$ \\ ${ }^{a}$ GEOMAR Helmholtz Centre for Ocean Research, Düsternbrooker Weg 20, 24105 Kiel, Germany \\ ${ }^{\mathrm{b}}$ Alfred-Wegener-Institute, Helmholtz Centre for Polar and Marine Research, Bussestraße 24, 27570 Bremerhaven, Germany
}

\section{A R T I C L E I N F O}

\section{Article history:}

Received 3 May 2013

Received in revised form

13 November 2013

Accepted 21 November 2013

Available online 10 December 2013

Keywords:

North Atlantic

Iceland Basin

Reykjanes Ridge

Overflow transport

Current meter observations

\begin{abstract}
A B S T R A C T
Here we present results from a combined moored current meter/hydrography array deployed within the Iceland Scotland Overflow Water (ISOW) plume on the eastern flank of Reykjanes Ridge approximately $1000 \mathrm{~km}$ downstream of Faroe Bank Channel (FBC) between June 2000 and August 2002. Based on the array measurements during this period the ISOW plume exhibited a time mean volume transport of $3.8 \pm 0.6 \mathrm{~Sv}$ (standard error, $1 \mathrm{~Sv}=10^{6} \mathrm{~m}^{3} / \mathrm{s}$ ). The transport estimate favorably compares with other recent estimates obtained by different methods, confirming that the fate of the ISOW plume downstream of the array is far from being fully understood. Historical observations show that drainage of ISOW through Charlie-Gibbs Fracture Zone (CGFZ) only amounts to $60 \%$ of our upstream transport estimate. To date, no reliable transport estimates of the fractions of ISOW recirculating within the Iceland Basin or being drained through fracture zones other than CGFZ do exist. Our observed 2-years-long transport time series show pronounced subseasonal variability with a standard deviation of $1.3 \mathrm{~Sv}$. Simultaneous hydrographic observations reveal, that temporal changes in the strength of the flow go along with changes in the water mass properties. Periods of stronger flow within the ISOW plume coincide with a reduction in salinity.
\end{abstract}

(c) 2013 Elsevier Ltd. All rights reserved.

\section{Introduction}

The North Atlantic limb of the three dimensional global circulation is split into two horizontal layers. At the surficial subpolar front one finds a northeastward drift of warm water masses from the subtropics. Originally they were advected by the Gulf Stream system and its extension east of the Grand Banks. After crossing the Mid-Atlantic Ridge the North Atlantic Current (NAC) develops increasingly large meanders or collapses in meso-scale eddies (Read et al., 2009), finally reaching the Norwegian Sea. Nonetheless well defined braches of the NAC can be identified (e.g., see Hakkinen and Rhines (2009), and references therein). Due to strongly variable atmospheric conditions these surface waters lose heat and buoyancy. As a consequence, dense water formation at intermediate depths occurs in the Nordic Seas and the transformed waters represent major sources of the lower layers of the global thermo-haline circulation. They feed into two intermediate subsurface overflows located on the northwestern and southeastern sides of Iceland, namely the Denmark Strait Overflow and Iceland Scotland Overflow, respectively Mauritzen (1996a,b). The latter drain

\footnotetext{
* Corresponding author at: Alfred-Wegener-Institute, Helmholtz Centre for Polar and Marine Research,B ussestraße 24, 27570 Bremerhaven, Germany.

Tel.: +49(0)471 4831 2913; fax: + 49 (0)471 48311797.

E-mail address: torsten.kanzow@awi.de (T. Kanzow).
}

the transformed cold water masses from the Nordic Seas through small subsurface channels where vigorous mixing occurs (e.g. Mauritzen et al., 2005; Fer et al., 2010). After further transformations and detours the resulting Denmark Strait Overflow Water (DSOW) and Iceland Scotland Overflow Water (ISOW) circulate cyclonically along the abyssal margins of the Irminger Basin towards the Labrador Sea (Käse et al., 2003). Here, these two stacked water masses are sporadically overlapped by variable vintages of convected, slightly lighter Labrador Sea Water (LSW) (Fischer et al., 2010). A significant fraction of the three stacked water masses - referred to as North Atlantic Deep Water (NADW), is exported from the subpolar gyre southward both by the deep western boundary current along the Americas (e.g., Fischer et al., 2004) and along pathways in the ocean interior (Bower et al., 2009; Lozier et al., 2010).

The fascinating transformation of ISOW within the sill area at the Faroe Bank Channel (FBC) has attracted numerous observational oceanographers for decades (Helland-Hansen and Nansen, 1909; Dietrich, 1956; Worthington, 1976; van Aken and Becker, 1996; Saunders, 1996; Hansen and Østerhus, 2000; Beairds et al., 2013). Practically all newly developed oceanographic instruments and equipment have been applied to the overflow phenomenon on both sides of Iceland. An extended review on all aspects of the ISOW plume near its source can be found in Hansen and Østerhus (2000). 


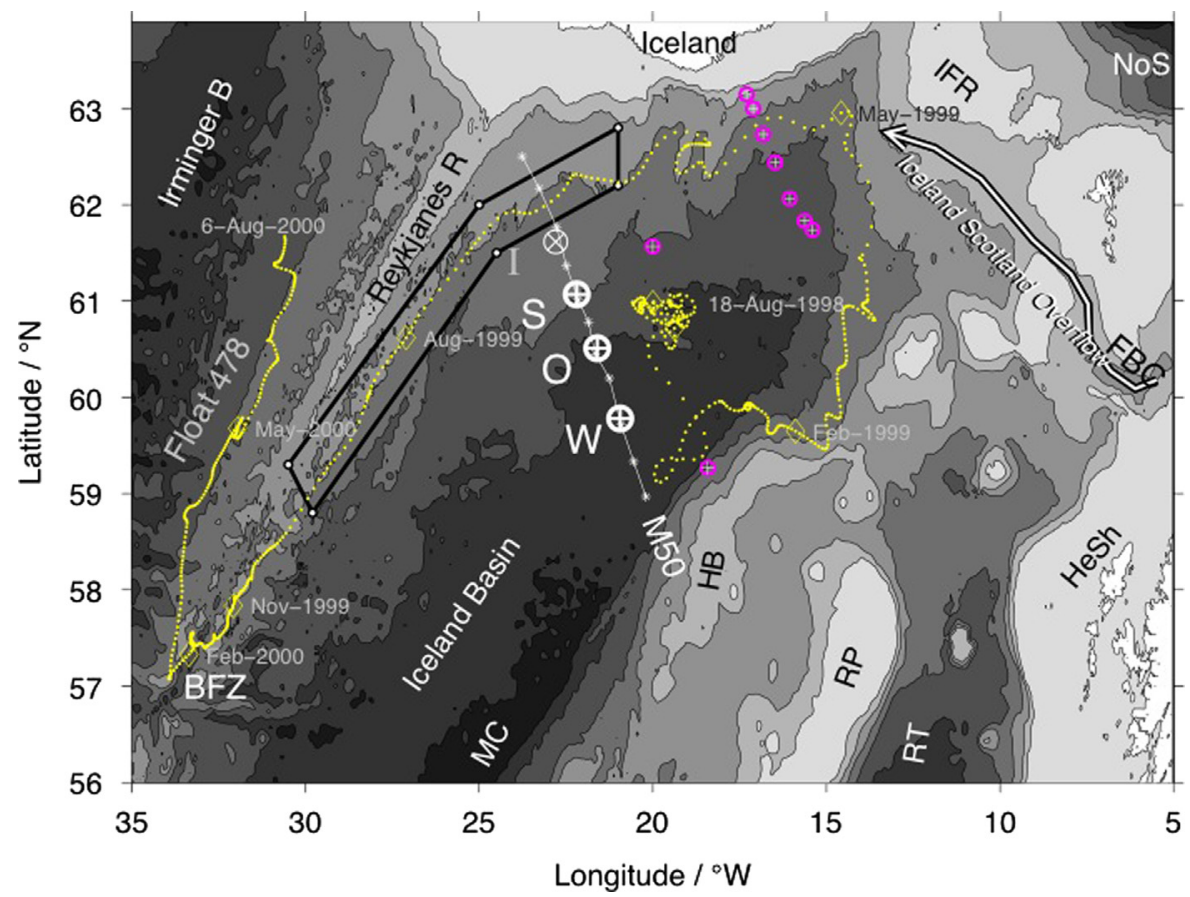

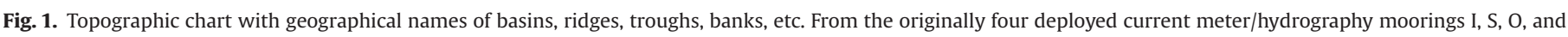

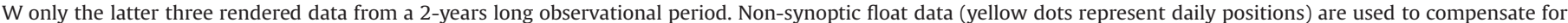

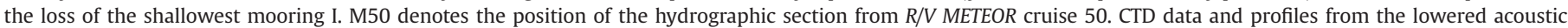

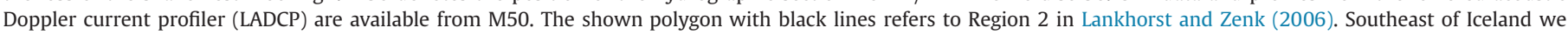

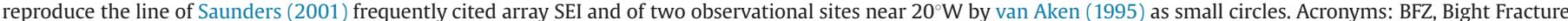

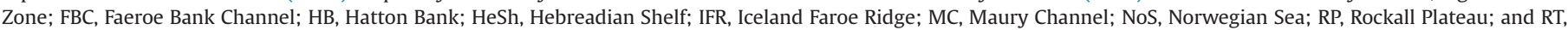
Rockall Trough.

In this paper we report on observations of the structure of the plume and its fluctuations from a section perpendicular to the eastern flank of Reykjanes Ridge roughly at the latitude of $61^{\circ} \mathrm{N}$, i.e. off the southwesterly descending extension of the Icelandic shelf (Ulrich, 1960). In Fig. 1 all geographic and logistic details are summarized. Our focus lies on the current meter/hydrography array "I-S-O-W", deployed in summer 2000 for 2 years, complemented by repeated hydrographic sections. Some Lagrangian aspects of the ISOW dynamics have already been discussed on the basis of RAFOS float observations (Lankhorst and Zenk, 2006). A fleet of these roving current meters circulated in the Iceland Basin prior to the Eulerian measurements presented here. The ISOW moorings were intentionally located about $1000 \mathrm{~km}$ downstream of the sill, so that most of the transformation of the ISOW plume induced by entrainment and mixing should have already taken place by the time the plume passes the array. Also, the location of the array was chosen to be upstream of the first major fracture zone within the Ridge. Farther downstream, the Bight and Charlie Gibbs Fracture Zones (BFZ, CGFZ) at $57^{\circ} \mathrm{N}$ and $53^{\circ} \mathrm{N}$, respectively, enable ISOW to discharge from the eastern side of the Reykjanes Ridge to become part of the subpolar intermediate circulation in the Irminger Basin. A Lagrangian perspective of the crossover flow of ISOW beyond the Reykjanes Ridge has been discussed by Bower et al. (2002). The float path shown in Fig. 1 demonstrates the westward throughput of ISOW through BFZ.

Observations of fluctuations of the ISOW plume are the focus of our investigations. We will discuss transport variations resolved by our recovered array of three current meter moorings. Our transport estimate of the ISOW plume of $3.8 \mathrm{~Sv}$ at $1000 \mathrm{~km}$ downstream of FBC is somewhat on the high end of historical estimates in the area. Still, it can be reconciled with appropriate lower values farther downstream, provided that a substantial loss of ISOW takes place through BFZ across the Ridge as postulated recently in model calculations by Xu et al. (2010).

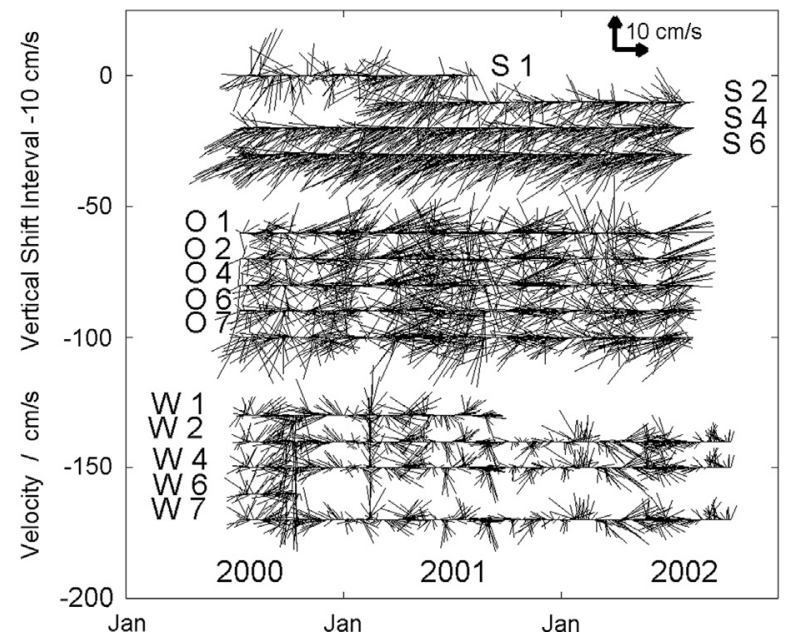

Fig. 2. Time series of observed velocity vectors from moorings $S, O$ and $W$ in geographic coordinates. For details and annotations see Table 1. Prior to plotting vectors were calculated from two-daily averages. Scale is given on top of the figure. North points upwards.

\section{Data and methods}

\subsection{Data}

\subsubsection{Mooring array}

The data set analyzed in this study relies on the "I-S-O-W" array, with each of the letters representing one mooring site. The array was deployed in the framework of the collaborative research center SFB 460 based at Kiel. An overview of the observed current meter data is compiled in Fig. 2 as series of vectors (stick diagram) in true geographical coordinates. Mooring locations are shown in 


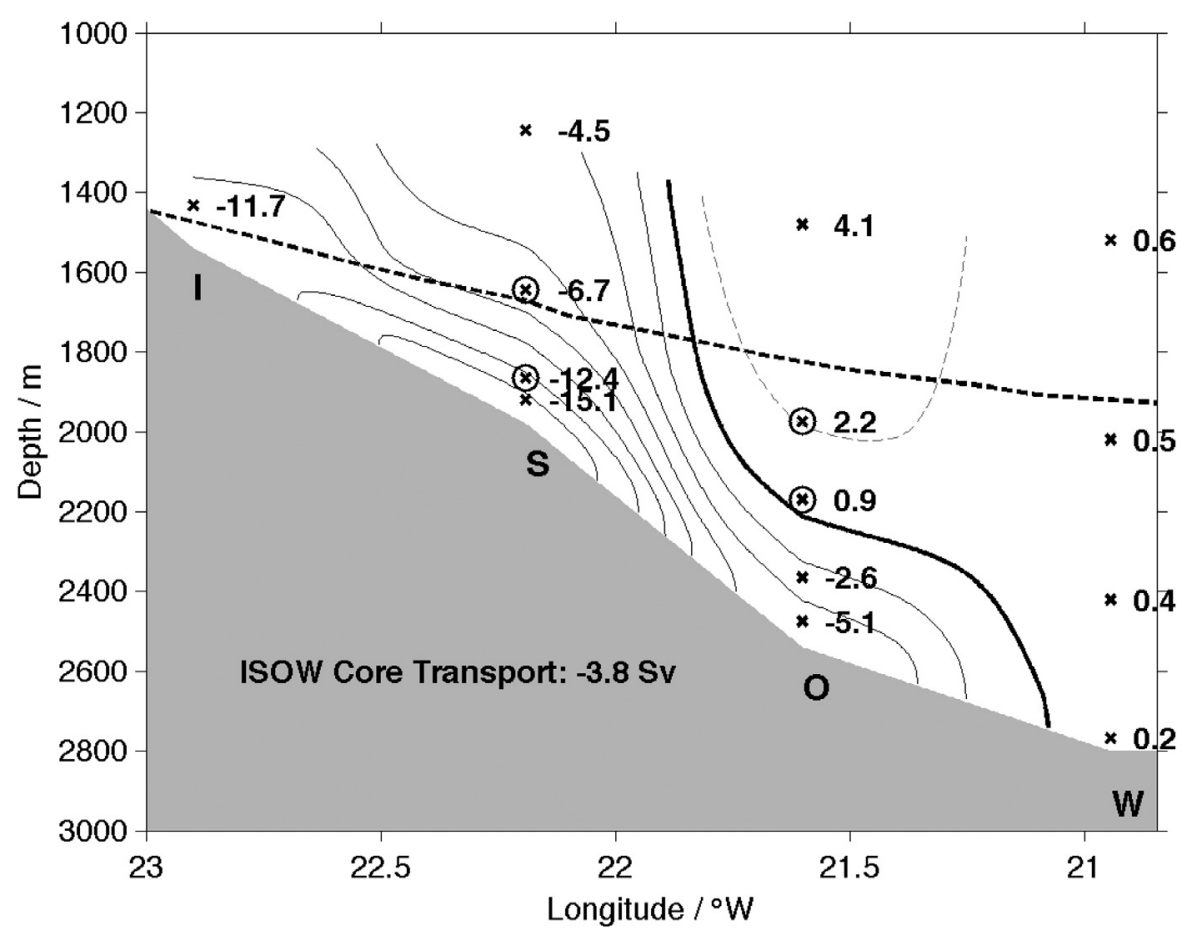

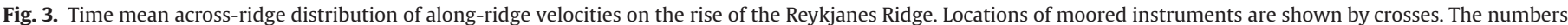

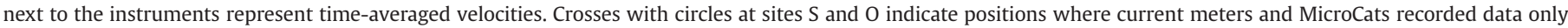

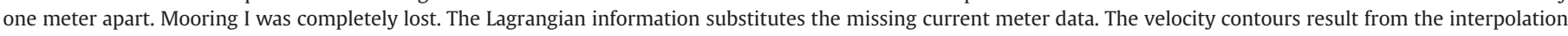

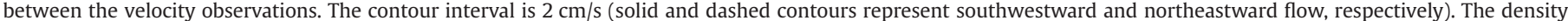

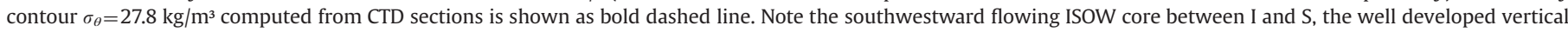

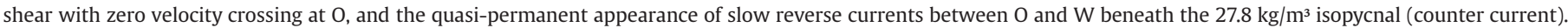
Instrument W6 (see Table 2; Fig. 2) is not shown, as it failed prematurely, and was therefore not used for the computation of the mean flow.

Fig. 1, and the vertical sensor distribution is displayed in Fig. 3 with details given in Table 1 . The line along which the four moorings where deployed in July 2000, extended across the eastern slope of Reykjanes Ridge from roughly $1500 \mathrm{~m}$ to $2800 \mathrm{~m}$ water depth. It was supposed to cover the total width of the ISOW plume.

Unfortunately the shallowest, western most rig (I) broke loose (Fig. 1) and did not return any data. The encountered loss, degrading the accuracy of our transport estimate, has partly been compensated by robust, though non-synoptic, Lagrangian data from earlier RAFOS trajectories (Fig. 1; Section 2.1.2).

Two of the remaining moorings were successfully recovered in August 2002 (S and O). Initially the recovery of W failed. However, this mooring was completely recovered 2 years later by our Norwegian colleague Dr. H. Søiland aboard R/V G.O. Sars during the MAR-ECO expedition (Søiland et al., 2008).

All moorings where equipped with Aanderaa RCM8 current meters. Mooring S had four current meters between $1245 \mathrm{~m}$ and $1920 \mathrm{~m}$, O had five current meters between 1480 and $2475 \mathrm{~m}$ while W had five current meters between 1520 and $2768 \mathrm{~m}$. With the choice of two-hourly sampling intervals we are able to resolve tidal variations. In order to obtain the velocity component along Reykjanes Ridge - required for the computation of the ISOW plume transport - the velocities are analyzed in a coordinate frame rotated by $63^{\circ}$ starting from the north direction. Time means in the topographic coordinate system are shown in Table 2.

In this study, we also make use of four time series of temperature and salinity. Two were observed by Microcat sensors at site $\mathrm{S}$, at $1646 \mathrm{~m}$ (instrument S3; see Table 2) and $1866 \mathrm{~m}$ (S5), and the other two at site O, at $1976 \mathrm{~m}$ (03) and $2171 \mathrm{~m}$ (05), respectively. The collected time series have a temporal resolution of $15 \mathrm{~min}$. Each of the four conductivity measurements were adjusted such, that their potential temperature-salinity characteristic matches best the characteristics shown by the calibrated lowered CTD (conductivity-temperature-depth) measurements (see later in Fig. 8) acquired along the mooring section during the R/V Meteor cruise 50 in summer 2001. The salinity offsets added to the records 03, 05, S3 and S5 were $+0.008,+0.008,+0.015$, and +0.010 , respectively. The salinity record S3 showed an abrupt, step-like change after 28 June 2001. By addition of a constant offset of +0.020 to all salinity values of S3 after this date, the step was efficiently removed.

\subsubsection{Float trajectories}

Numerous well resolved float trajectories from intermediate depths (1500-2600 m) within the Iceland Basin are available between 1997 and 2003. They originate primarily from two coordinated research initiatives, Kiel SFB 460 and EUROFLOAT. One goal of these efforts was "to document the pathways, mean flows, and flow variability of water parcels in the Iceland Basin" (Lankhorst and Zenk, 2006). In that study, the authors chose selected locations to demonstrate prevailing spreading and mixing of water masses in the northeastern Atlantic. One of the highly energetic regions parallels the eastern flank of Reykjanes Ridge as a smallish strip between $62^{\circ} \mathrm{N}$ and $59^{\circ} \mathrm{N}$ (shown as slim polygon in Fig. 1). The part of the trajectory of RAFOS float 478 , which was recorded in late summer of 1999, is contained in the polygon. Fairly equidistant, daily tick marks of this particular trajectory indicate a stable flow with high directional stability (Fig. 1).

In search for a replacement for the lost data from mooring I, we determined an averaged velocity of $11.7 \mathrm{~cm} \mathrm{~s}^{-1}$ from the trajectory of float 478 along Reykjanes Ridge during the period 15 May12 October 1999, when it was close to site I. From all available trajectories this path lies closest to the lost mooring, which had been equipped with one current meter within the ISOW plume. Float 478 
Table 1

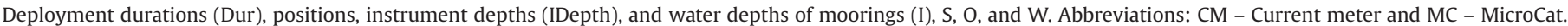

\begin{tabular}{|c|c|c|c|c|c|c|c|c|}
\hline & Start of record & End of record & Dur (days) & Latitude $\left({ }^{\circ} \mathrm{N}\right)$ & Longitude $\left({ }^{\circ} \mathrm{W}\right)$ & IDepth (m) & Depth (m) & Inst (type) \\
\hline Mooring (I) & & Lost & & 61.615 & 22.796 & & & \\
\hline Mooring S & & & & 61.069 & 22.191 & & 1966 & \\
\hline S1 & 11-July-2000 & 14-August-2001 & 400 & & & 1245 & & $\mathrm{CM}$ \\
\hline $\mathrm{S} 2$ & 18-March-2001 & 11-August-2002 & 512 & & & 1645 & & $\mathrm{CM}$ \\
\hline S3 & 11-July-2000 & 11-August-2002 & 762 & & & 1846 & & MC \\
\hline $\mathrm{S} 4$ & 11-July-2000 & 11-August-2002 & 762 & & & 1865 & & $\mathrm{CM}$ \\
\hline S5 & 11-July-2000 & 11-August-2002 & 762 & & & 1866 & & MC \\
\hline S6 & 11-July-2000 & 08-August-2002 & 758 & & & 1920 & & $\mathrm{CM}$ \\
\hline Mooring $\mathrm{O}$ & & & & 60.508 & 21.601 & & 2526 & \\
\hline 01 & 10-July-2000 & 13-July-2002 & 733 & & & 1480 & & $\mathrm{CM}$ \\
\hline $\mathrm{O} 2$ & 10-July-2000 & 10-August-2002 & 762 & & & 1975 & & $\mathrm{CM}$ \\
\hline 03 & 10-July-2000 & 10-August-2002 & 762 & & & 1976 & & MC \\
\hline $\mathrm{O} 4$ & 10-July-2000 & 10-August-2002 & 762 & & & 2170 & & $\mathrm{CM}$ \\
\hline O5 & 10-July-2000 & 10-August-2002 & 762 & & & 2171 & & MC \\
\hline O6 & 10-July-2000 & 10-August-2002 & 762 & & & 2365 & & $\mathrm{CM}$ \\
\hline 07 & 10-July-2000 & 10-August-2002 & 762 & & & 2475 & & $\mathrm{CM}$ \\
\hline Mooring W & & & & 59.780 & 20.944 & & 2819 & \\
\hline W1 & 08-July-2000 & 30-August-2001 & 418 & & & 1520 & & $\mathrm{CM}$ \\
\hline W2 & 08-July-2000 & 14-October-2002 & 828 & & & 2020 & & $\mathrm{CM}$ \\
\hline W4 & 08-July-2000 & 14-October-2002 & 828 & & & 2420 & & $\mathrm{CM}$ \\
\hline W6 & 08-July-2000 & 21-October-2000 & 105 & & & 2660 & & $\mathrm{CM}$ \\
\hline W7 & 08-July-2000 & 14-October-2002 & 828 & & & 2768 & & $\mathrm{CM}$ \\
\hline
\end{tabular}

Table 2

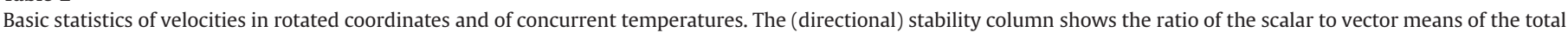

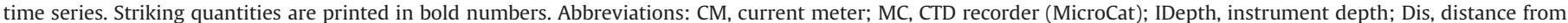

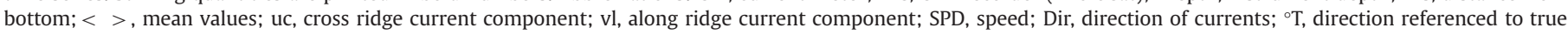
north coordinates; Stab, vector stability; T, in situ temperature; EKE, eddy kinetic energy; and MKE, mean kinetic energy.

\begin{tabular}{|c|c|c|c|c|c|c|c|c|c|c|c|c|c|c|c|}
\hline $\begin{array}{l}\text { Moor } \\
\text { Type }\end{array}$ & & $\begin{array}{l}\text { IDepth } \\
\text { m }\end{array}$ & $\begin{array}{l}\text { Dist } \\
\mathrm{m}\end{array}$ & $\begin{array}{l}\text { Duration } \\
\text { days }\end{array}$ & $\begin{array}{l}\mathrm{OK} \\
\%\end{array}$ & $\begin{array}{l}\langle\mathrm{uc}\rangle \\
\mathrm{cm} / \mathrm{s}\end{array}$ & $\begin{array}{l}\langle\mathrm{vl}\rangle \\
\mathrm{cm} / \mathrm{s}\end{array}$ & $\begin{array}{l}\langle\mathrm{SPD}\rangle \\
\mathrm{cm} / \mathrm{s}\end{array}$ & $\begin{array}{l}\text { Dir } \\
{ }^{\circ} \mathrm{T}\end{array}$ & Stab & $\begin{array}{l}\langle T\rangle \\
{ }^{\circ} \mathrm{C}\end{array}$ & $\begin{array}{l}\operatorname{Std}(T) \\
{ }^{\circ} \mathrm{C}\end{array}$ & $\begin{array}{l}\mathrm{EKE} \\
(\mathrm{cm} / \mathrm{s})^{2}\end{array}$ & $\begin{array}{l}\text { MKE } \\
(\mathrm{cm} / \mathrm{s})^{2}\end{array}$ & MKE/EKE \\
\hline \multicolumn{16}{|c|}{ Mooring S } \\
\hline S1 & $\mathrm{CM}$ & 1245 & 721 & 400 & 52 & 1.1 & -4.4 & 4.5 & 229 & 0.46 & 4.246 & 0.254 & 54.68 & 10.24 & 0.19 \\
\hline S2 & CM & 1645 & 321 & 512 & 67 & -0.3 & -7.4 & 7.4 & 245 & 0.74 & 3.392 & 0.119 & 40.14 & 27.57 & 0.69 \\
\hline S3 & MC & 1646 & 320 & 762 & 100 & & & & & & 3.437 & 0.119 & & & \\
\hline S4 & CM & 1865 & 101 & 762 & 100 & 0.1 & -12.4 & 12.4 & 242 & 0.90 & 2.882 & 0.140 & 38.93 & 76.53 & 1.97 \\
\hline S5 & MC & 1866 & 100 & 762 & 100 & & & & & & 2.935 & 0.141 & & & \\
\hline S6 & CM & 1920 & 46 & 758 & 99 & -0.3 & -15.1 & 15.1 & 244 & 0.93 & 2.732 & 0.145 & 42.59 & 114.03 & 2.68 \\
\hline \multicolumn{16}{|c|}{ Mooring O } \\
\hline 01 & $\mathrm{CM}$ & 1480 & 1046 & 733 & 96 & 0.3 & 4.0 & 4.1 & 67 & 0.39 & 3.564 & 0.134 & 71.99 & 8.23 & 0.11 \\
\hline $\mathrm{O} 2$ & CM & 1975 & 551 & 762 & 100 & 0.3 & 2.2 & 2.3 & 71 & 0.20 & 3.291 & 0.064 & 85.78 & 2.54 & 0.03 \\
\hline $\mathrm{O} 3$ & MC & 1976 & 550 & 762 & 100 & & & & & & 3.301 & 0.066 & & & \\
\hline $\mathrm{O} 4$ & CM & 2170 & 356 & 762 & 100 & 0.1 & 0.9 & 0.9 & 71 & 0.08 & 3.122 & 0.076 & 93.52 & 0.40 & 0.00 \\
\hline $\mathrm{O} 5$ & MC & 2171 & 355 & 762 & 100 & & & & & & 3.251 & 0.079 & & & \\
\hline 06 & CM & 2365 & 161 & 762 & 100 & 0.4 & -2.6 & 2.6 & 234 & 0.24 & 2.923 & 0.079 & 82.82 & 3.49 & 0.04 \\
\hline O7 & CM & 2475 & 51 & 762 & 100 & 0.5 & -5.1 & 5.1 & 237 & 0.43 & 2.623 & 0.089 & 82.26 & 13.25 & 0.16 \\
\hline \multicolumn{16}{|c|}{ Mooring W } \\
\hline W1 & $\mathrm{CM}$ & 1520 & 1299 & 418 & 50 & 0.4 & 0.6 & 0.7 & 95 & 0.09 & 3.819 & 0.180 & 39.01 & 0.25 & 0.01 \\
\hline W2 & $\mathrm{CM}$ & 2020 & 799 & 828 & 100 & 0.3 & 0.4 & 0.5 & 104 & 0.07 & 3.354 & 0.064 & 29.42 & 0.12 & 0.00 \\
\hline W3 & MC & 2022 & 797 & & 0 & (Failed) & & & & & & & & & \\
\hline W4 & CM & 2420 & 399 & 828 & 100 & 0.2 & 0.3 & 0.3 & 97 & 0.05 & 3.130 & 0.056 & 32.89 & 0.06 & 0.00 \\
\hline W5 & MC & 2422 & 397 & & 0 & (Failed) & & & & & & & & & \\
\hline W6 & $\mathrm{CM}$ & 2660 & 159 & 105 & 13 & 1.1 & 0.2 & 1.1 & 143 & 0.13 & 2.913 & 0.066 & 40.62 & 0.60 & 0.01 \\
\hline W7 & CM & 2768 & 51 & 828 & 100 & -0.1 & 0.1 & 0.2 & 20 & 0.02 & 2.708 & 0.064 & 31.42 & 0.01 & 0.00 \\
\hline
\end{tabular}

had an averaged drifting depth of $1433 \mathrm{~m}$ during the selected averaging period.

\subsubsection{Ship-borne observations}

CTD section data are available from three cruises, with the first (R/V Poseidon cruise 261) taking place in July 2000 (array deployment), the second (R/V Meteor cruise 50) in July 2001 and the third (R/V Poseidon cruise 293) in August 2002 (array recovery). The positions of the CTD stations from M50 across the ISOW plume are shown in Fig. 1. From the CTD data the density level $\sigma_{\theta}=27.8 \mathrm{~kg} / \mathrm{m}^{3}$ was computed (Fig. 3) representing the spatial average of the three sections mentioned above. In agreement with many earlier studies, this contour was chosen to define the upper boundary of the ISOW plume in our ISOW transport calculations.

In the case of cruise M50 supplemental profiles from a selfcontained lowered acoustic Doppler current recorder (LADCP $150 \mathrm{kHz}$ ) are available in $10 \mathrm{~m}$ depth intervals. The LADCP consisted 
of an upward and a downward looking sensor package. More information on CTD and LADCP performances can be found in the cruise report (http://oceanrep.geomar.de/14701/1/m50-4.pdf).

\subsection{Methods}

In order to compute volume transport of the ISOW plume a spatial interpolation of our long-term current meter records was carried out as follows.

First, the incomplete time series (Fig. 2) of the instruments S1 (failed after 14 August 2001), S2 (corrupted data before 18 March 2001) and W1 (failed after 30 August 2001) were filled, using linear regressions with time series from the same mooring during periods where the abovementioned instruments produced reliable data (in each case the correlations between the affected and unaffected time series were above 0.9).

The Eulerian means were calculated uniformly from all current meter time series. The record from the second lowest instrument W6 with only $13 \%$ data return was omitted from the analysis. Since mooring I was not recovered, for the calculation of the ISOW plume transport we used a value of $11.7 \mathrm{~cm} / \mathrm{s}$ for the alongboundary flow speed at this site at $1433 \mathrm{~m}$, as computed from a float trajectory (see Section 2.1.2).

In order to preserve the expected shape of the overflow plume leaning against the eastern flank of Reykjanes Ridge in the twodimensional spatial mapping, we chose to transform the depth coordinate $z$ into a quasi-terrain-following vertical coordinate $h_{s}$ as follows:

$h_{s}(x)=\left(z_{b}(x)-z_{i}(x)\right) /\left(z_{b}(x)-z_{T}(x)\right)$,

where $x, z_{b}, z_{i}$, and $z_{t}$ denote the horizontal distance, the water depth, the instrument depth, and the depth of the top-most instrument at each mooring. In the $x-h_{s}$ plane (with $h_{s}$ taking values between 0 and 1) a 2D interpolation using the Gaussian weights was performed with the Gaussian half-widths of $22 \mathrm{~km}$ and 0.05 for $x$ and $h_{s}$.

With these settings, the current meter data were interpolated onto a grid with resolutions of $6 \mathrm{~km}$ and 0.02 for $x$ and $h_{\mathrm{s}}$, respectively. The gridded velocity field was subsequently transformed back to $x-z$ space with a vertical spacing of $20 \mathrm{~m}$.

The bottom depth profile and a spatially averaged isopycnal layer of $\sigma_{\theta}=27.8 \mathrm{~kg} / \mathrm{m}^{3}$ (inferred from the three service CTD surveys) limit the integration area for our transport estimate on the lower and upper sides of the flux section. The vertical position of the chosen isopycnal is robust. We learned from the two adjoined temperature/salinity sensors in mooring $\mathrm{S}$ across the interface that the standard deviation of its vertical displacement is only of order $\pm 30 \mathrm{~m}$ within the 2-years long observation period. Finally, to estimate ISOW plume transports, we integrate the along-ridge velocities below $\sigma_{\theta}=27.8 \mathrm{~kg} / \mathrm{m}^{3}$ from the Reykjanes Ridge out to the location where the flow reverses (zero speed contour in Fig. 3).

This mapping technique was applied for three cases: (i) overall time mean, (ii) 60-days pieces (overlapping by 30 days) resulting in a transport time series, and (iii) a selected "snapshot" representing the maximum transport (i.e., interval between 3 July and 1 September 2001). As measurements of the time variable flow were unavailable at site I (see above) the float inferred velocity value of $11.7 \mathrm{~cm} / \mathrm{s}$ was used for each of the mapped fields.

The latter overlaps the M50 hydrographic survey, which took place in late July 2001. Some caution is required, as the limited horizontal resolution of the flow (as set by the mooring separations), might cause the interpolation scheme to produce a too wide plume. For the computation of the transport from the mooring data, we kept the velocity at site I fixed at each time step at a value of $11.7 \mathrm{~cm} / \mathrm{s}$, as inferred from the float data (see Section 2.1.2).

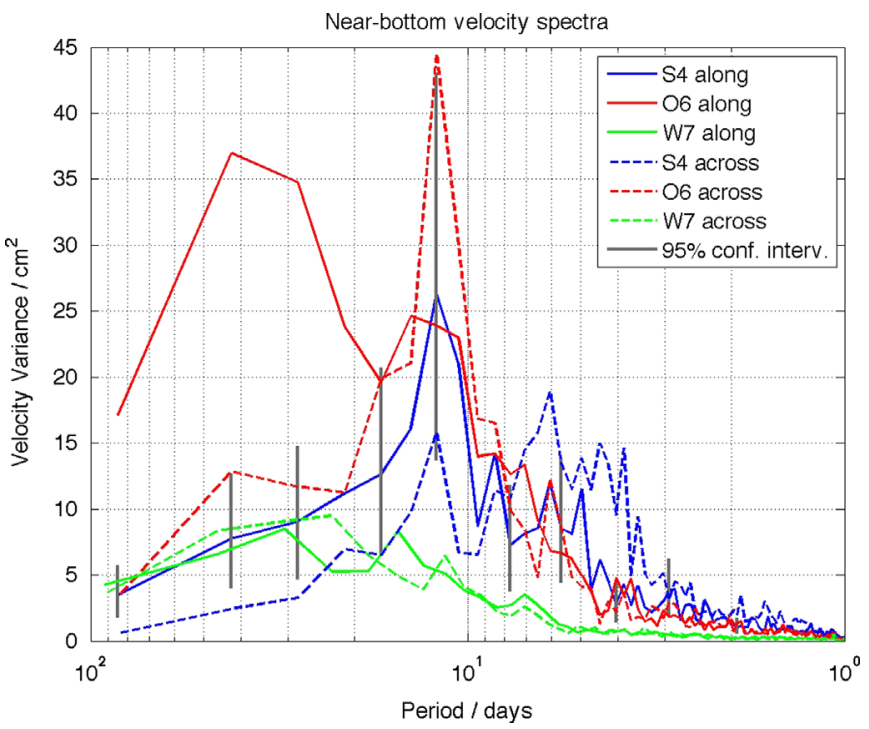

Fig. 4. Variance conserving spectra of velocity components from the curren meters S4 in moorings S (blue), 06 (red) and W7 (green). The velocity components along and across Reykjanes Ridge are shown as solid and dashed lines, respectively For instrument details see Table 2. Exemplarily, the 95\% confidence interval (for selected periods) for the along-ridge component of S4 is denoted by vertical, gray lines.

\section{Results}

\subsection{Time mean flow and transport}

In the discussion of our observational results we start with a time mean flow distribution of the ISOW plume, as inferred from the current meter array. Fig. 3 shows the velocity contours on the section across the eastern flank of Reykjanes Ridge at nominally $61^{\circ} \mathrm{N}$. All available current records according to Table 2 are included. A closer look at the stability parameter (ratio of scalar to vector means) in Table 2 (bold numbers) demonstrates how closely the core of the ISOW plume at $\mathrm{S}$ is bound to the near-floor layer with high velocities ( $>12 \mathrm{~cm} / \mathrm{s}$ ). The ratio between mean and eddy kinetic energies at site $\mathrm{S}$ approaches or even exceeds the value of 2 which is characteristic for descending overflow plumes or other contour currents (Zenk, 2008).

Water masses with $\sigma_{\theta}>27.8 \mathrm{~kg} / \mathrm{m}^{3}$ in the Iceland Basin are commonly defined as ISOW. With this interface as an upper boundary and the zero speed contour as the eastern margin we can integrate the southwesterly currents on the section from west to east. The time mean zero speed contour slopes downward toward the southeast, intersecting with mooring $\mathrm{O}$ and reaching out to mooring $\mathrm{W}$ near the sea floor (Fig. 3). We obtain a mean transport of $-3.8 \mathrm{~Sv}$ with a standard error of $0.6 \mathrm{~Sv}$, assuming eight degrees of freedom. This represents our best estimate of the time mean ISOW plume transport across the mooring section. However, if we include in the integration the weak counter current (i.e., the northeastward flow residing between the $27.8 \mathrm{~kg} / \mathrm{m}^{3}$ isopycnal and the zero contour at the eastern part of the section covered by the mooring array) the volume transport below the $27.8 \mathrm{~kg} / \mathrm{m}^{3}$ isopycnal reduces to $-3.4 \mathrm{~Sv}$.

\subsection{Time-variable flow}

In the following, the observed temporal variability of current velocities in the ISOW plume is analyzed. The aims are both to quantify, and to understand the origin of the fluctuations. One application is to define a time scale, beyond which the impact on the velocities by short-term fluctuations possibly caused by eddies 
or current meanders is reduced. This information is subsequently used for the computation of a time series of the ISOW transport.

Table 2 displays the eddy kinetic energy (EKE) of all current meter records. At each of the three mooring sites the EKE is distributed fairly uniformly over the observed depth ranges (with no apparent changes across the $27.8 \mathrm{~kg} / \mathrm{m}^{3}$ interface). However, there are large differences between the moorings, with the EKE level near $80 \mathrm{~cm}^{2} / \mathrm{s}^{2}$ at the central site (O) being approximately twice as large as at the other two sites (with EKE at $\mathrm{S}$ being slightly larger than at W). Fig. 3 reveals, that site $\mathrm{O}$ corresponds to the outer edge of the ISOW plume, while $\mathrm{S}$ and $\mathrm{W}$ are located within and outside of the plume, respectively. It is also interesting to note, that the velocity variance in the direction along the Reykjanes Ridge is 2.5 times as large as in the across-ridge direction at $\mathrm{O}$, whereas it is only 1.6 and 1.3 times as large at the sites S and W, respectively (not shown).

In order to classify the temporal variability of the observed velocities in the density regime of the ISOW plume, power spectra of one (representative) current meter record per mooring below the $27.8 \mathrm{~kg} / \mathrm{m}^{3}$ isopycnal were computed. Fig. 4 shows the results for the current meters in mooring S (blue, instrument S4 at $1865 \mathrm{~m}$ depth), in mooring $\mathrm{O}$ (red, instrument $\mathrm{O} 6$ at $2365 \mathrm{~m}$ ), and in mooring W (green, instrument W7 at $2768 \mathrm{~m}$ ) for both the velocity component along and across Reykjanes Ridge (solid and dashed lines, respectively). The aim is to detect preferred time scales of variability, which might differ with distance from the Reykjanes Ridge crest, and might either be a result of changes of the ISOW plume (pulsing and meandering), topographic waves approaching the Reykjanes Ridge, or eddies.

As noted above, at site $\mathrm{O}$ the along-ridge velocity component has generally much larger variance than the across-ridge component with a peak near 30 days, strongly dropping off at periods longer than 40 days. The across-ridge component exhibits a pronounced peak near 11.7 days - displaying larger variance than the along-ridge component at this period. It could be due to bottom trapped motions, as both, clockwise or anticlockwise rotations of the coordinate system reduce the variance of this velocity component. This 11.7 days signal is present throughout the entire record, with the amplitude varying substantially over time (not shown). The signal is inconsistent with fortnightly tides.

Strikingly, in the ISOW core (site S) a peak near 11.7 days is also present, however, mostly in the along-ridge component. At higher frequencies (3-7 days band) more variance is found in the acrossridge than in the along-ridge component. Thus both sites $\mathrm{S}$ and $\mathrm{O}$ show the tendency that higher frequency motions are dominated by across ridge velocity fluctuations while low frequency motions are dominated by along-ridge velocity fluctuations. This characteristic can be expected from linear, topographically-trapped Rossby waves (Rhines, 1970). We will follow up on this aspect in Section 4.

There is no stable phase relationship between the 11.7 days signals at the sites $\mathrm{O}$ and $\mathrm{S}$, and it is unclear, whether they represent a spatially coherent signal driven by the same mechanism. At $S$ the amplitude of the along-ridge velocity component exceeds that of the across ridge one, but is considerably weaker than the along-ridge component at $\mathrm{O}$. At the offshore site $\mathrm{W}$ the variability is substantially weaker, both in the along-ridge and across-ridge components. In essence, the 2-years-long current time series indicates that the southwestward flow of the ISOW plume almost exclusively occurs west of our offshore site W.

Overall, the above statistical analysis implies that wave-like fluctuations in the ISOW plume and at its margin may mask fluctuations of the plume itself on time scales shorter than about 40 days. In order to reduce the contamination of our ISOW plume transports estimates by the topographic waves, we computed a transport time series using 60-days averaged, monthly values (Fig. 5). The unfortunate loss of mooring (I) caused a slight

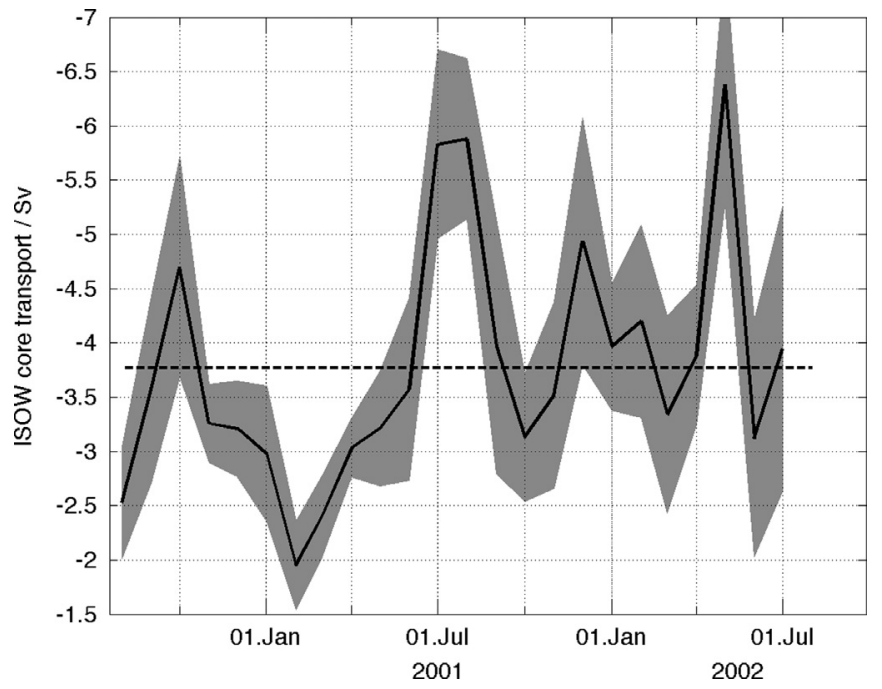

Fig. 5. Monthly transport time series computed from 60-days averaged velocity data. The mean is indicated by the stippled line. The gray envelope is composed of the standard errors of transport estimates for each of the 60-days intervals. For each 60-days segment, the standard error was calculated in several steps. First, we estimated the vertically averaged degrees of freedom of the velocity time series at each mooring site. From this we computed the velocity standard error at each site. The latter was then multiplied by an influence radius ( $40 \mathrm{~km}$ for both I and $\mathrm{W}$, and $80 \mathrm{~km}$ for both S and O) and by the ISOW plume height at each site to obtain the transport standard errors associated with each site. Finally the total ISOW plume standard error was obtained from the square root of the sum of the squared transport standard errors associated with each site. Note that the total transport standard error is not constant over time, but rather reflects the month-to-month changes in both the short-term velocity fluctuations and the average plume height.

deficiency at the western margin of the current meter array. Here we replaced fluctuating current values by a constant $(-11.7 \mathrm{~cm} / \mathrm{s})$ as derived from float observations. However, the transport estimates are not particularly sensitive to the current velocity at site I. An uncertainty of $\pm 5 \mathrm{~cm} / \mathrm{s}$ induces an uncertainty in the ISOW transport estimate of just $\pm 0.3 \mathrm{~Sv}$.

Despite the averaging, this time series still displays a sizeable intraseasonal variability with a standard deviation of $1.3 \mathrm{~Sv}$. The ISOW plume is well-developed throughout most of the time series, with the lowest value being found in early March and the highest value in July 2001. The across-ridge distribution of along-ridge flow during the event of maximum transport ( $30 \mathrm{~h}$ beginning on mid-night 22 July 2001) from the moored measurements is displayed in Fig. 6a. The quasi-synoptic LADCP velocity section is displayed in Fig. 6b along the moored array obtained in the same interval. An earlier version of the LADCP section with extended width at both figure sites (see Fig. 1), can be found in Fig. 4.11a of the R/V Meteor 50 cruise report (Zenk et al., 2002). Hence, both data sets (moored vs. LADCP) were collected simultaneously by completely independent methods. Nevertheless, we find a reasonable agreement between both data sets.

In fact, both sections in Fig. 6 show the expected partition into two anti-parallel flows of the same magnitude on the eastern sites. The main branches in the centers of both subfigures represent the bottom intensified ISOW core, while the eastern countercurrent is generally less uniformly defined. However, in the case of the R/V Meteor 50 survey a comparison with the salinity section reveals that the deep counter current is directly connected with a high salinity feature in the main thermocline. This deep reaching cone, also seen in Fig. 6b, might possibly be part of the North Atlantic Current or an eddy detached from it. Its velocity signature is covered by three adjacent LADCP casts (Casts 18-20 (outside the shown figure)). The mooring-derived and the LADCP based section in Fig. 6a display a tilted zero velocity contour between $21.8^{\circ}$ and $21.0^{\circ} \mathrm{W}$, while its equivalent in Fig. $6 \mathrm{~b}$ indicates increased 
a

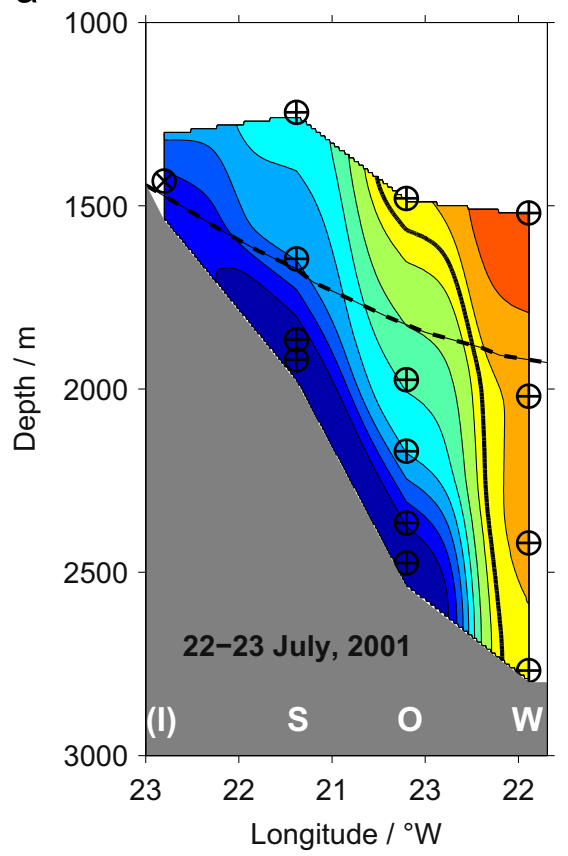

b

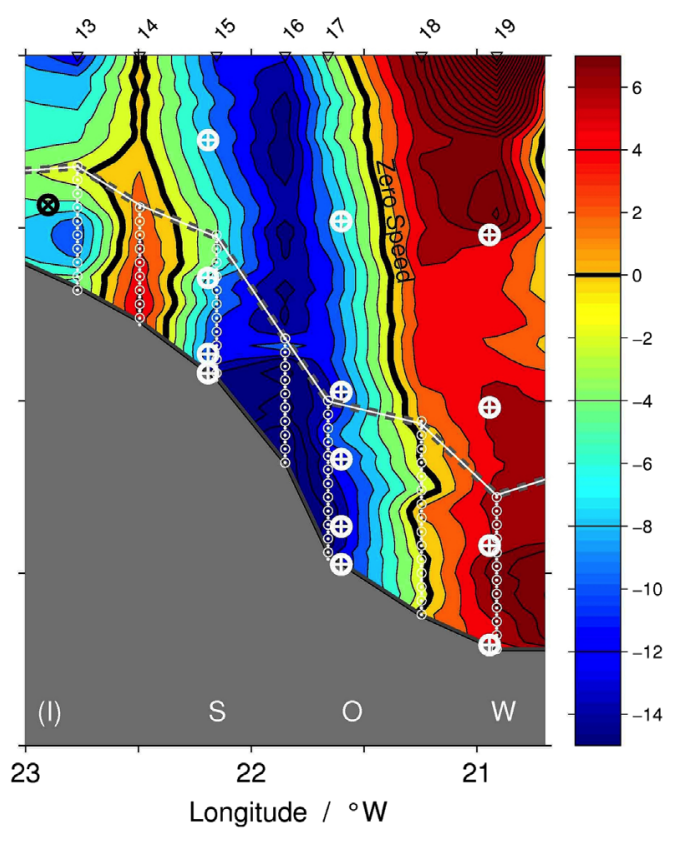

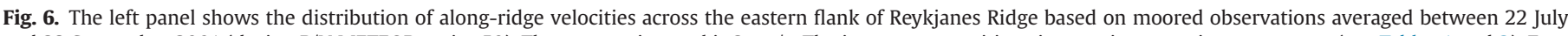

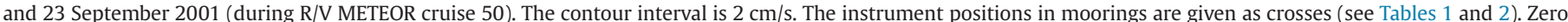

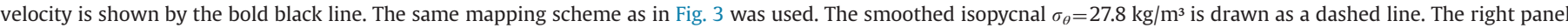

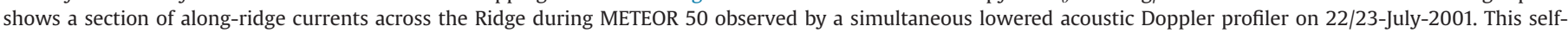

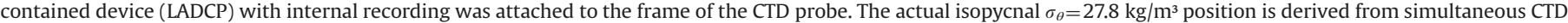

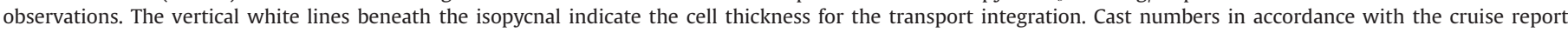
(Zenk et al., 2002) are shown on top of b.

Table 3

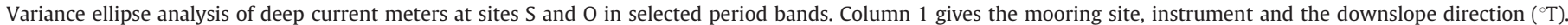

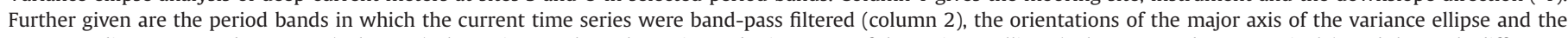

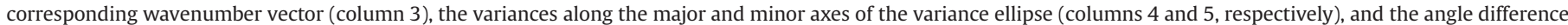
between the wavenumber vector and downslope.

\begin{tabular}{|c|c|c|c|c|c|}
\hline $\begin{array}{l}\text { Mooring/instrument } \\
\text { (downslope direction/ } /{ }^{\circ} \text { ) }\end{array}$ & $\begin{array}{l}\text { Period } \\
\text { [days] }\end{array}$ & $\begin{array}{l}\text { Major axis of ellipse } /{ }^{\circ} \mathrm{T} \\
\text { (wavenumber vector } /{ }^{\circ} \mathrm{T} \text { ) }\end{array}$ & $\begin{array}{l}\text { Variance along major } \\
\text { ellipse axis } / \mathrm{cm}^{2} \mathrm{~s}^{-2}\end{array}$ & $\begin{array}{l}\text { Variance along minor } \\
\text { ellipse axis } / \mathrm{cm}^{2} \mathrm{~s}^{-2}\end{array}$ & $\begin{array}{l}\text { Angle difference between } \\
\text { wavenumber vector and downslope }\end{array}$ \\
\hline $\mathrm{S} / 4\left(154^{\circ}\right)$ & $25-55$ & $55(145)$ & 5.3 & 1.7 & -9 \\
\hline $\mathrm{S} / 4\left(154^{\circ}\right)$ & 09-18 & $112(202)$ & 14.4 & 5.8 & 48 \\
\hline $\mathrm{S} / 4\left(154^{\circ}\right)$ & $03-08$ & $164(254)$ & 10.2 & 5.3 & 100 \\
\hline $0 / 6\left(175^{\circ}\right)$ & $25-55$ & $86(176)$ & 22.1 & 5.3 & 1 \\
\hline $0 / 6\left(175^{\circ}\right)$ & 09-18 & $138(228)$ & 15.3 & 10.9 & 53 \\
\hline $0 / 6\left(175^{\circ}\right)$ & 03-08 & 93 (183) & 4.8 & 4.4 & 8 \\
\hline
\end{tabular}

horizontal shear. Because of the much higher vertical sampling rate of the LADCP profiles compared to the mooring-inferred profiles, the former resolve smaller-scale velocity structures. ISOW transports calculated from both sections yield similar numbers. We estimate $-7.1 \mathrm{~Sv}$ for the short-term moored section in Figs. 6a, $-6.4 \mathrm{~Sv}$ for the LADCP snapshot displayed in Figs. 6b, and $-7.5 \mathrm{~Sv}$ for the expended LADCP section occupied during M50 (see Fig. 1). In all cases we use the $\sigma_{\theta}=27.8$ isopycnal shown in Fig. 3 as upper boundary. All counter flow signatures were excluded from the horizontal integration.

\section{Discussion}

We have presented mean ISOW transports of $3.8 \mathrm{~Sv}$ inferred from our 2-years long current meter array at about $61^{\circ} \mathrm{N}$. The transport time series displays considerable variability on subseasonal time scale. Based on two-monthly intervals we find a standard deviation for ISOW transports of $\pm 1.3 \mathrm{~Sv}$, resulting in a standard error of $\pm 0.6 \mathrm{~Sv}$ (using eight degrees of freedom). We have also demonstrated the existence of a northeastward flow of $+0.4 \mathrm{~Sv}$ below the $27.8 \mathrm{~kg} \mathrm{~m}^{-3}$ isopycnal near the offshore end of our array. Thus, roughly $10 \%(0.4 \mathrm{~Sv})$ of the water mass in the classic ISOW layer is thus seen to penetrate far into the deep Iceland Basin and might either mix with the lower saline water masses originating from the Labrador Sea or alternatively feed into the ISOW plume further upstream. The actual recirculation might even be larger, as the array most likely did not cover all the recirculation.

It was mentioned that topographic Rossby waves (TRW) might explain the observed frequency dependence of the variance partition between the along-ridge and across-ridge velocity components. This aspect will subsequently be discussed using the dispersion relation for TRWs in a stratified ocean as applied by Pickart and Watts (1990),

$\tau N \gamma \sin \varphi=2 \pi \tanh \left(2 \pi N D / \lambda f_{0}\right)$

with $\tau, N, \gamma, \varphi, D, \lambda$, and $f_{0}$ representing the period, the BruntVäisälä frequency, the bottom slope, the orientation angle of phase 


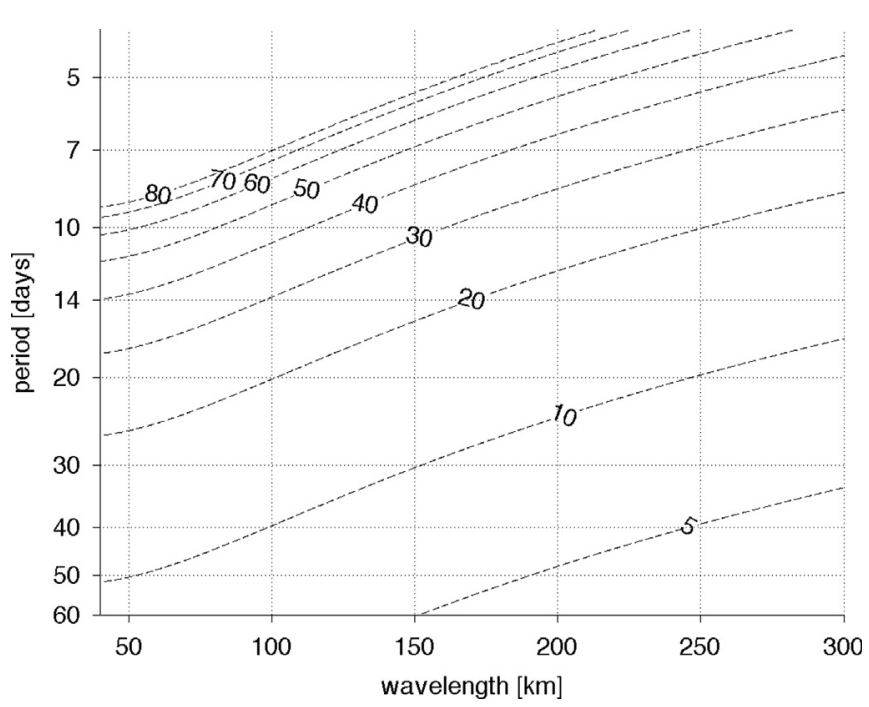

Fig. 7. Dispersion relation of linear topographic Rossby waves in a stratified ocean (see Pickart and Watts, 1990). The contours represent the phase speed orientation angle (relative to downslope) as a function of wave periods [days] and wavelength [km]. For the computation $N=0.001 \mathrm{~s}^{-1}, \gamma=0.008$ and $D=2000 \mathrm{~km}$ were used (see text).

velocity from downslope, the characteristic water depth and the Coriolis parameter, respectively. In the low-frequency limit of TRWs exclusively offshore phase propagation is expected. Facing downslope, towards higher frequencies, the direction of phase propagation should turn clockwise (i.e., in such a way that shallower water depths are located to the right of the vector). In the high-frequency limit exclusively along-shore propagation should be observed.

Johns and Watts (1986) and Pickart and Watts (1990) used a variance analysis of moored velocity measurements to study TRWs in the deep Gulf Stream and North Atlantic deep western boundary current, respectively. For TRWs, the wavenumber vector (i.e. the direction of the phase speed) is supposed to be orthogonal to the major axis of the variance ellipse of the velocity fluctuations (pointing offshore).

We computed velocity variance ellipses in three period bands (25-55 days, 9-18 days, and 3-8 days) as guided by our spectral analysis (Fig. 4) at sites S (instrument S4) and O (instrument O6) using band passed velocity fluctuations (the spectra at site $\mathrm{W}$ do not suggest the presence of TRWs). In five of the six cases (three period bands applied to two instruments) summarized in Table 3 we find significantly more variance along the major axes of the variance ellipses than along the corresponding minor axes (Table 3; columns 4 and 5), pointing to the presence of TRWs. Only the case instrument 06 in the high frequency limit, the distribution of variance appears to be isotropic. This case will not be discussed further.

At low frequencies (in the 25-55 days band) both sites $\mathrm{S}$ and $\mathrm{O}$ at major axes are within $10^{\circ}$ of the along-bathymetry direction (Table 3; columns 1, 3, and 6) suggesting almost exclusively downslope phase speeds. According to the above dispersion relation, phase speed orientations relative to downslope between $0^{\circ}$ and $20^{\circ}$ are expected (Fig. 7). In the 9-18 days band the major axes have turned clockwise by $50^{\circ}$ at both sites $\mathrm{S}$ and $\mathrm{O}$, suggesting a phase propagation oriented $\varphi=50^{\circ}$ to downslope. A clockwise rotation toward higher frequencies is expected from the theory of TRWs. Using characteristic values of $N=0.001 \mathrm{~s}^{-1}, \gamma=0.008$ and $D=2000 \mathrm{~km}$ in the above dispersion relation of TRWs, $\varphi=50^{\circ}$ would correspond relatively wavelengths near $50 \mathrm{~km}$ (Fig. 7). This might explain the lack of coherence between the fluctuations

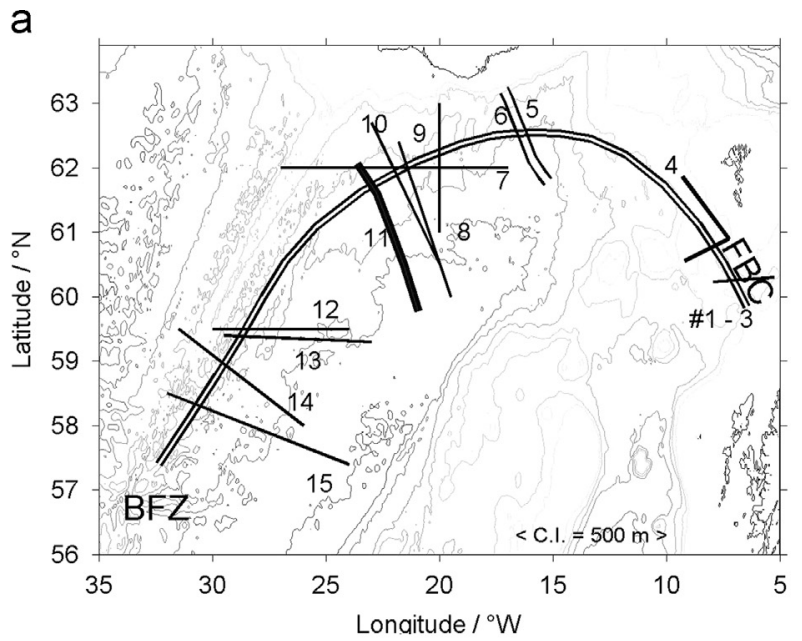

b

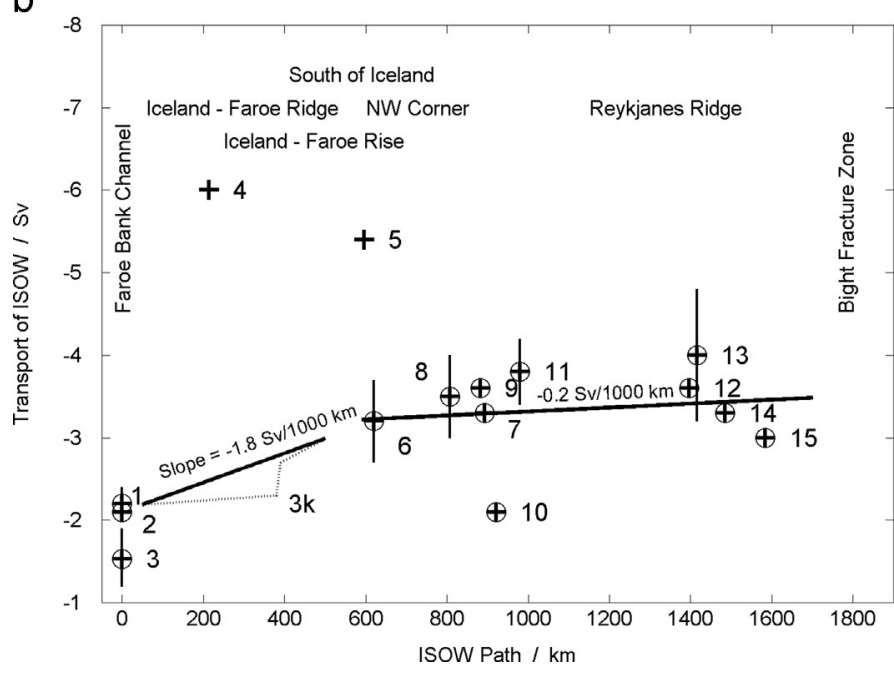

Fig. 8. Generalized pathway of the ISOW plume between the Faroe Bank Channel and the Bight Fracture Zone (a) and increase of ISOW transport presumably due to vertical and lateral entrainment along this path (b). Numbers refer to flux quantities found in the literature (see Table 4). Uncircled crosses in (b) remained unconsidered in the calculation of transport increase. Case \#3 represents nine sources according to Hansen and Østerhus (2000) plus the latest estimate (\#3k) by Beairds et al. (2013). The two straight lines indicate linear fits in a least-squares sense. The stippled line in the region downstream of the Faroe Bank Channel in (b) symbolizes the overflow gain from the crest of the Iceland-Faroe Ridge as reported in \#3k. \#11 reflects observational results of this study.

observed between sites $\mathrm{S}$ and $\mathrm{O}$. At the highest frequencies under consideration (3-8 days) the major variance axis at site $S$ is almost aligned with the downslope orientation, suggesting almost alongslope phase propagation. According to the theory, this again points to rather short wave lengths $<100 \mathrm{~km}$. In summary, our observations might be explainable by linear TRWs. One should mention that the determination of the appropriate downslope orientation of the topography bears uncertainties. The spatial scale at which the downslope orientation should be inferred from, might actually be dependent on the wavelength of the TRWs. Also, the computation of the major axis of the variance ellipse is subject to uncertainty. In total, we estimate that the two effects add up to an overall error in $\varphi$ of roughly $10^{\circ}$.

Our mean ISOW transport estimate favorably compares with the recent quantification of the ISOW $(-4.0 \pm 0.8 \mathrm{~Sv})$ obtained by Sarafanov et al. (2012) using repeated hydrographic surveys near $59.5^{\circ} \mathrm{N}$. Also the offshore return current of $+0.3 \pm 0.7 \mathrm{~Sv}$ in their observations at $59.5^{\circ} \mathrm{N}$ compares well with our results. 
Table 4

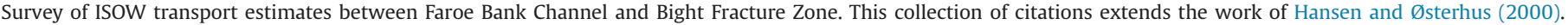
Case numbers are reproduced in Fig. 8. Though negative signs have been omitted, all flux rates show a westward and/or southward direction.

\begin{tabular}{|c|c|c|c|}
\hline Case \# & Author(s) & Flux/Sv & Method \\
\hline 1 & Xu et al. (2010) & 2.2 & $1 / 12^{\circ}$ Eddy resolving model \\
\hline 2 & Olsen et al. (2008) & 2.1 & Observations, model simulations \\
\hline \multirow[t]{2}{*}{3} & Hansen and Østerhus (2000) & Compreh. mean $1.6 \pm 0.5$ (std. dev.) & Summary of nine cases $(3 a-3 i)$ \\
\hline & Hansen and Østerhus (2007) & $2.1 \pm 0.2$ from velocity field & 10 years update, long-term ADCP, hydrography \\
\hline $3 a$ & Hermann (1967) & 1.4 & Hydrography \\
\hline $3 b$ & Sætre (1967) & 1.5 & Short-term moorings, hydrography \\
\hline $3 c$ & Rydberg (1980) & 1.2 & Hydrolic theory, hydrography \\
\hline $3 d$ & Dooley and Meincke (1981) & 1.4 & Short-term moorings, hydrography \\
\hline $3 e$ & Borenäs and Lundberg (1988) & $1.7\left(T<3^{\circ} \mathrm{C}\right)$ & Hydrolic theory, ship-borne obs. \\
\hline $3 f$ & Saunders (1990) & $1.9\left(T<3{ }^{\circ} \mathrm{C}\right)$ & Long-term moorings, hydrography \\
\hline $3 g$ & Saunders (1992) & $1.3 \pm 0.4$ (std. err.) $\left(T<3{ }^{\circ} \mathrm{C}\right)$ & Ship-borne acoustic Doppler profiler (ADCP) \\
\hline $3 \mathrm{~h}$ & Østerhus et al. (1999) & $1.9\left(T<3^{\circ} \mathrm{C}\right)$ & Long-term ADCP, hydrography \\
\hline $3 \mathrm{i}$ & Østerhus et al (1999) & $1.5\left(T<0.5^{\circ} \mathrm{C}\right)$ & Long-term ADCP, hydrography \\
\hline $3 \mathrm{k}$ & Beaird et al. $(2013)^{a}$ & $1.8 \pm 0.2$ & Multiyear Seaglider surveys, hydrography, RAFOS floats \\
\hline 4 & Dietrich (1956) & $\sim 6$ & Hydrography, uncertain topography \\
\hline 5 & Steele et al. (1962) & 5.4 & Exploratory Lagrange obs., classic hydrography \\
\hline 6 & Saunders (1996) & $3.2 \pm 1.4$ (std. dev.) or \pm 0.5 (std. err.) & 13 months, 13 moored current meters \\
\hline 7 & Krauss (1995) & 3.3 & Hydrography, satellite tracked buoys \\
\hline 8 & van Aken (1995) & 3.5 & Repeat hydrography, mooring data \\
\hline 9 & van Aken and Becker (1996) & 3.6 & Hydrography \\
\hline 10 & Harvey and Theodorou (1986) & 2.1 & Large-scale hydrography \\
\hline 11 & This study & $3.8 \pm 1.3$ (std. dev.) or \pm 0.5 (std. err.) & 2 years long moorings, 14 current meters, RAFOS floats \\
\hline 12 & Sarafanov et al. (2012) & $4.0 \pm 0.8$ (std. err.) & Repeat hydrography, satellite altimetry \\
\hline 13 & Worthington and Volkmann (1965) & 3.6 & Hydrography \\
\hline 14 & Xu et al (2010) & 3.3 & $1 / 12^{\circ}$ eddy resolving model \\
\hline 15 & Bacon (1997) & 3.0 & Large-scale hydrography, inverse modeling \\
\hline
\end{tabular}

a Added in revision phase, November 2013.

Our ISOW transport estimate can be integrated in a long series of historical estimates (Table 3). In Fig. 8 we display the location (a) and magnitude (b) of 15 transport estimates of the ISOW plume on its pathway between the Faroe Bank Channel and the Bight Fracture Zone of the Reykjanes Ridge. The path was constructed on the base of a typical trajectory (RAFOS float 478) as seen in Fig. 1. This float started its exemplary mission in the central Iceland Basin on 18 August 1998 and returned to the surface on the western flank of the Reykjanes Ridge on 6 August 2000. Its initial anticyclonal circulation is well in accordance with the stream function at $1500-1700 \mathrm{~m}$ derived from the manifold Lagrangian observations in the northeastern Atlantic (Bower et al., 2002).

Where available, error bars in Fig. $8 \mathrm{~b}$ indicate uncertainties given by the authors of the original works. Numbers (\#) denote citations collected in Table 4. This table can be seen as an extension of Table 4 in Hansen and Østerhus (2000) where the authors have concentrated and commented their search for flux data through the FBC from the literature. The latter table contains nine different quantifications between 1967 and 1999. Although they rely on fairly different definitions, methods, and periods, they all converge at about $-1.6 \pm 0.5 \mathrm{~Sv}$ of initial ISOW in the Iceland Basin (\#3 in Fig. 8). We are aware of two more citations (\#1 and 2) that we added in continuation of Hansen and Østerhus's summary table. Two older estimates (\#4 and 5) by Dietrich (1956) and Steele et al. (1962) are included in Fig. 8 as well. They appear unlikely in the light of newer repeat observations with more advanced methods and numerical model results, and are therefore neglected in the following discussion. The presently most accepted transport estimate of dense water $\left(\sigma_{\theta}>27.8 \mathrm{~kg} \mathrm{~m}^{-3}\right)$ through FBC based on more than 10 years of continuous moored observations is $2.1 \pm 0.2 \mathrm{~Sv}$ (Hansen and Østerhus, 2007). This value serves us as a starting point for the transport estimates of the ISOW plume within the Iceland Basin (Fig. 8b).

Following the pathway $600 \mathrm{~km}$ downstream of the sill in the FBC (Fig. 8a) we encounter Saunders's (1996) frequently cited result of $-3.2 \pm 0.5 \mathrm{~Sv}$ obtained from a year-long moored array (\#6) of 13 current meters (Fig. 8b). As in our own estimate (\#11)

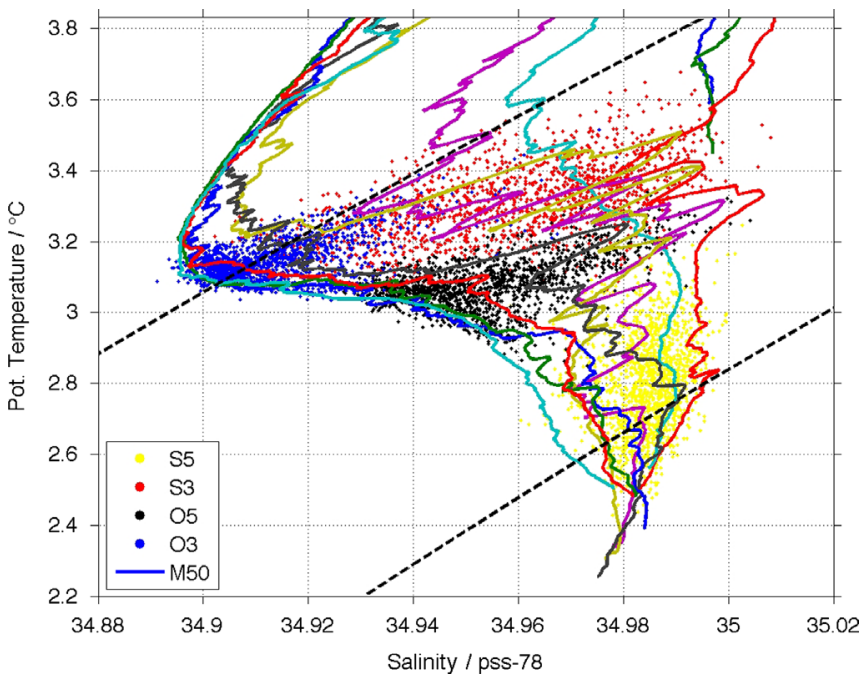

Fig. 9. Potential temperature-salinity diagram using profiles from the R/V Meteor cruise 50 taken along the ISOW mooring line (solid lines) and moored CTD measurements from the sites $\mathrm{S}$ and $\mathrm{O}$, taken at two depth levels each (dots). The bold dashed lines represent the 27.8 and $27.9 \mathrm{~kg} \mathrm{~m}^{-3}$ isopycnals.

the author computed a transport time series for ISOW defined by $\sigma_{\theta}>27.8 \mathrm{~kg} \mathrm{~m}^{-3}$. In essence, $600 \mathrm{~km}$ downstream of the sill the ISOW plume transport has reached a significant increase ( $1.8 \mathrm{~Sv} /$ $1000 \mathrm{~km}$ ) of its initial magnitude. In how far the augmentation of transport south of the Icelandic slope can be attributed to entrainment of water masses from above alone remains questionable. In contrast, spilling of dense water over the Iceland-Faroe Ridge can contribute to the significant flux increase of the ISOW plume along the first few hundred kilometers downstream of the FBC (Dooley and Meincke, 1981). Beairds et al. (2013) published the first multiyear Seaglider study from the northern margin of the Iceland Basin. Their work quantifies the overflow gain of approximately $0.8 \mathrm{~Sv}$ across the Iceland-Faroe Ridge (IFR) downstream of 
A

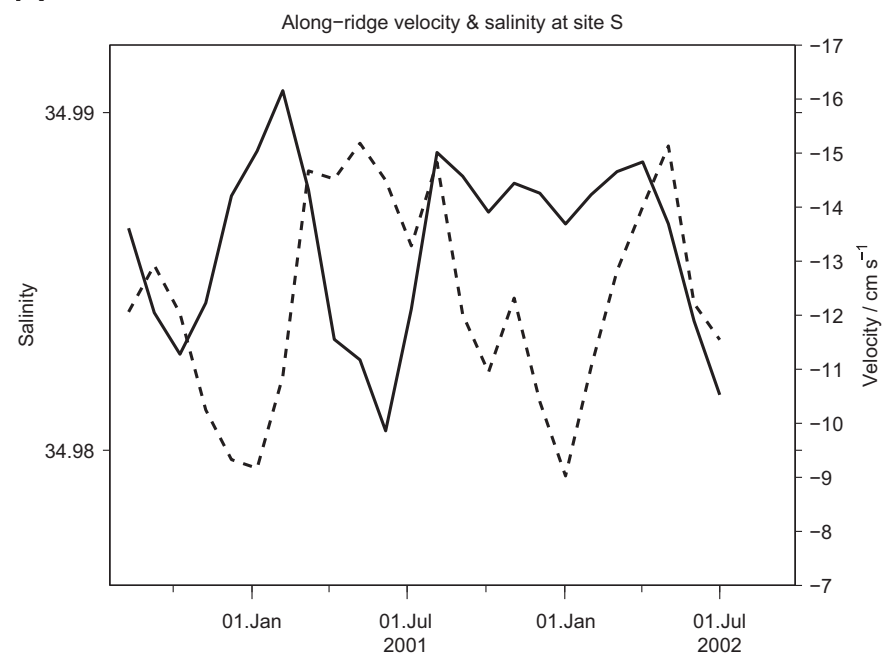

B

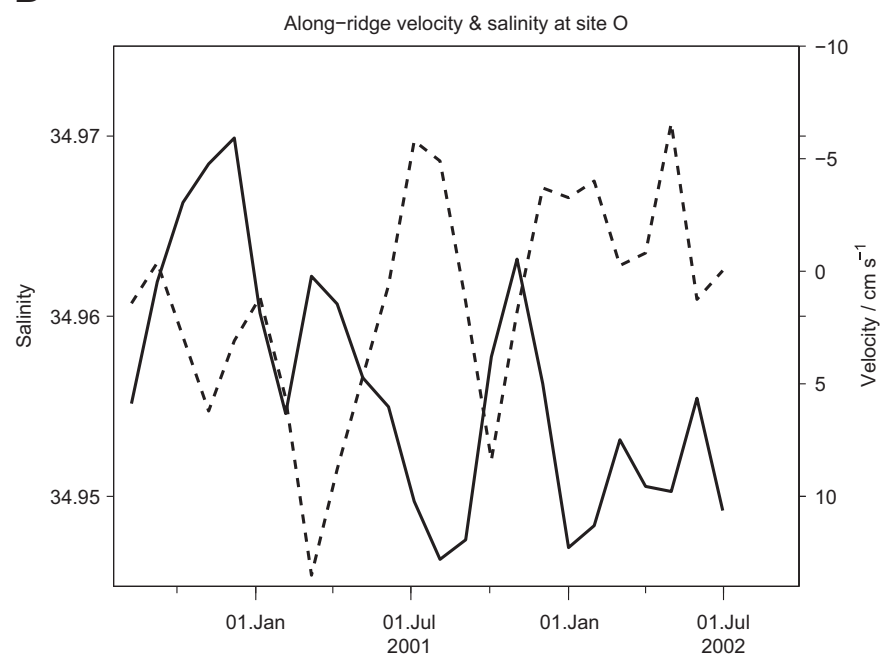

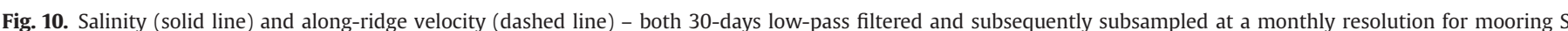

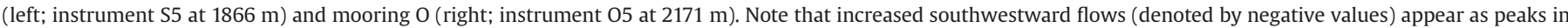
these panels. Also note the ranges for both velocity and salinity are larger for site $\mathrm{O}$ than for site $\mathrm{S}$.

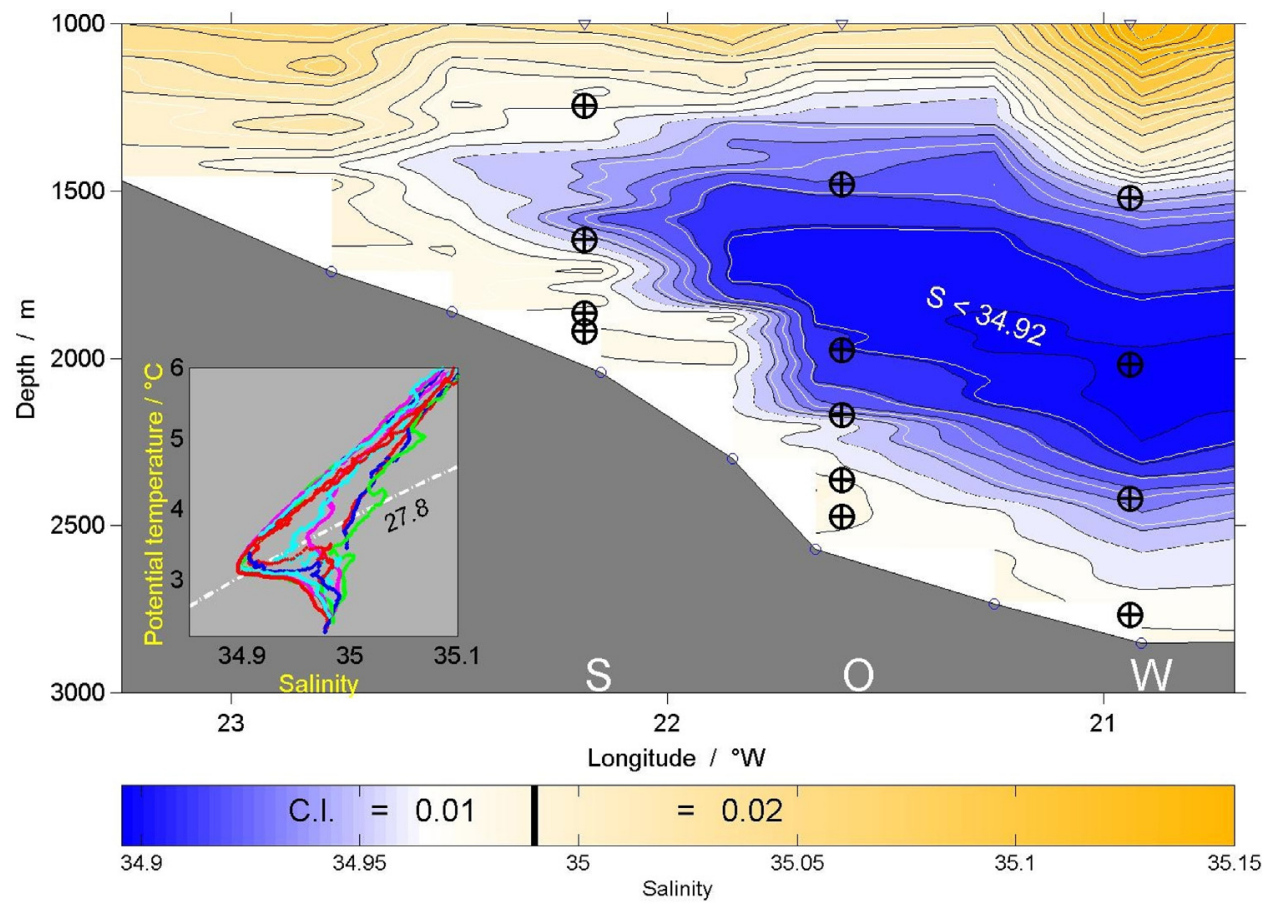

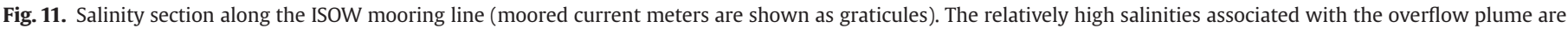

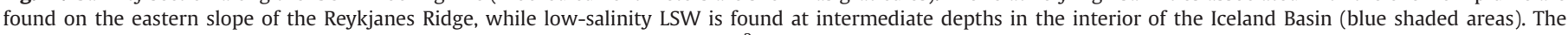
inserted $\theta-S$ diagram indicates the range of local variations below $\sigma_{\theta}=27.8 \mathrm{~kg} / \mathrm{m}^{3}$ density level. C.I. $=$ contour interval.

the Faroe-Bank Channel. This result is in accordance with earlier scarce estimates and underlines the key function of the Ridge with its far reaching impact on the Atlantic intermediate and bottom circulations. The sum of FBC and IFR overflows (2.9 Sv) would leave a contribution from entrainment of ambient waters into the ISOW plume of $0.3 \mathrm{~Sv}$ within the first $600 \mathrm{~km}$ from the sill.

Further downstream along the Reykjanes Ridge to the BFZ at $\sim 56^{\circ} \mathrm{N}$ ISOW transport estimates (\#8-15) scatter on a wider range. The averaged transport increase of advected ISOW declines to only $0.2 \mathrm{~Sv} / 1000 \mathrm{~km}$. This estimate should be viewed with caution. The transport estimates of Harvey and Theodorou (1986, \#10) and of Bacon (1997, \#15) represent particularly low estimates of ISOW transports. Both are based on large scale circulation patterns (without specific relation to the Reykjanes Ridge) and are difficult to allocate to a precise location. In spite of the observed considerable fluctuations we can classify the overflow in the northeastern Iceland Basin into two regimes: on the initial $\sim 600 \mathrm{~km}$ of the overflow cascade we find a rapid increase of the plume volume. In the following $1000 \mathrm{~km}$ transport increase rates are reduced by about one order of magnitude.

On short time scales, of course, eddies or topographic waves on the continental slope (Johns and Watts, 1986) might affect the strength and structure of the ISOW plume. We found some evidence that current variability on time scale between several days and up to 
a few weeks might indeed be affected by topographic Rossby waves. Spatial displacements of the upper ocean North Atlantic Current have been discussed as possible drivers of intraseasonal fluctuations of the deep flow near the Mid-Atlantic Ridge (Schott et al., 1999; Bower and von Appen, 2008). The LADCP section shown in Fig. $6 \mathrm{~b}$ hinted at a possible impact of upper ocean flows on the strength of the deep circulation considered here. Inspired by this finding, we conducted an analysis using observations of the geostrophic flow field at the sea surface based on remote sensing covering the 2-years period, when the array was deployed (not shown). However, we were unable to convincingly demonstrate that the observed multimonthly changes in ISOW transports (shown in Fig. 5) were driven by the eddy-rich upper ocean flow field. The results were very sensitive to the spatial scales over which the upper-ocean flow field was integrated.

The velocity and transport changes observed by the array are accompanied by changes in the hydrographic characteristics. The range of the potential temperature/salinity $(\theta-S)$ variability observed at depths deeper than the $27.8 \mathrm{~kg} \mathrm{~m}^{-3}$ isopycnal in the moorings $\mathrm{S}$ and $\mathrm{O}$ over the 2 years of observations (dots in Fig. 9) agrees favorably with the $\theta-S$ range observed in the cross-ridge hydrographic section along the mooring array. The moored CTD data might therefore be well used to study the hydrographic variability. Fig. 10 shows changes in the along-ridge velocity superimposed on salinity observed within the ISOW plume (i.e. at depths deeper than the $27.8 \mathrm{~kg} \mathrm{~m}^{-3}$ isopycnal). Both the salinity and flow variations are clearly larger at the offshore edge of the plume (site 0 ) than inside the plume (site S). The correlations between salinity and flow anomalies at the sites $\mathrm{S}$ and $\mathrm{O}$ are 0.4 and 0.6 , respectively. At $5 \%$ error probability, the correlation at site $\mathrm{O}$ is at the edge of being significant, while at site $\mathrm{O}$ it not significant (assuming nine degrees of freedom). Intraseasonal fluctuations in both transport and salinity in our observations are found to be strongest on the offshore flank of the plume. We therefore assume that meanders/recirculations and the associated lateral water mass exchange between the plume and the ambient waters dominate this period band rather than downslope advection.

At both moorings $\mathrm{S}$ and $\mathrm{O}$ pronounced southwestward flow of the plume is accompanied by lower salinities. This result may come as a surprise, because it suggests stronger flow within the ISOW plume to be associated with a higher percentage of lowsalinity LSW (Yashayaev et al., 2007). One might therefore speculate that stronger plume flow goes along with larger entrainment of LSW from the interior of the Iceland Basin (see Fig. 9). Indications for entrainment (stirring) are certainly visible in the $\theta-S$ profiles from the hydrographic cruise in July 2001 (M 50) at the transition between the plume and the basin interior water masses (Fig. 11). The M50 cruise took place during an episode of particularly pronounced southwestward flow at both sites S and $\mathrm{O}$.

\section{Conclusion}

Hydrographically the Iceland Basin appears as a well sampled region of the North Atlantic. Its assumed enormous climatic relevance for northern Europe reflected in the heat transport by the in- and overflows into and out of the Nordic Seas has attracted scientific studies for many decades. In so far it is astonishing that relatively little is known about the volumetric budget of ISOW entraining LSW along the Reykjanes Ridge. The climatologically forced, eddy-resolving Atlantic simulation model by Xu et al. (2010) suggests a substantial loss of ISOW of 1.2 Sv toward the Irminger Basin through gaps in the ridge north of CGFZ (such as Bight Fracture Zone; see their Fig. 4). Such a loss is necessary to reconcile the long lasting inconsistency between the upstream transport of $3.2 \mathrm{~Sv}$ at about $62.5^{\circ} \mathrm{N}$ (Saunders, 1996) and the drainage of $2.4 \mathrm{~Sv}$ through CGFZ at about $53^{\circ} \mathrm{N}$ (Saunders, 1994).
Earlier the Lagrangian observations have demonstrated exemplarily at least two additional conduits from the Iceland Basin for ISOW: Bight Fracture Zone (Lankhorst and Zenk, 2006) and farther south a continuation path on the eastern side of the Mid-Atlantic Ridge beyond $53^{\circ} \mathrm{N}$ (Machín et al., 2006). The latter can be interpreted as an intermediate western boundary current in the central North Atlantic. Both sinks for a branching ISOW plume have already been suggested earlier on the basis of geological evidences and due to intermediate tracer distributions east of the Mid-Atlantic Ridge, respectively (Shor et al., 1980; Fleischmann et al., 2001). Our new results from the current meter array at $61^{\circ} \mathrm{N}$ $(-3.8 \mathrm{~Sv})$ suggest even a further increase of the ISOW plume beyond the Saunders (1996) array at $62.5^{\circ} \mathrm{N}$. The rising transport confirms and amplifies the necessity for additional exits or recirculation paths for ISOW in the Iceland Basin. Unfortunately no dedicated Eulerian observations from the Bight Fracture Zone are available.

We conclude our paper with a citation from Saunders' (2001) review article "The detailed descent path of the overflow [along the slope of the Reykjanes Ridge] is unknown...". We are confident that the observational results of this study will help to solve $\mathrm{Xu}$ et al.'s (2010) puzzle. In fact, they do unveil further uncertainties along the path possibly in accordance with model simulations of the latest generation. The kinematic properties of the observed overflow plume will serve as test cases for coming model studies urgently needed for climate change prediction.

\section{Acknowledgments}

Thanks to Dr. H. Søiland's help on the R/V G.O. Sars the drifting mooring $\mathrm{W}$ was located and recovered en-route in the northern Iceland Basin. A later inspection of the two parallel acoustic releases confirmed that critical shafts in both releases had stalled due to corrosion. In fact, after 4 years of deployment the connecting chain between the two redundant devices had been completely corroded and it enabled the unexpected and complete recovery of $\mathrm{W}$. We further acknowledge the help of Captains and Crews of all the involved research vessels. Special thanks go to our peer T.J. Müller who was of invaluable assistance during the work at sea and in the early data processing phase. The financial support was provided by the Deutsche Forschungsgemeinschaft, Bonn, in the framework of SFB 460. With gratitude WZ acknowledges the work of his Ph.D. advisor, the late Professor G. Dietrich as one of the hydrographic pioneers in the Iceland Basin at the mid-term of the last century.

\section{References}

Bacon, S., 1997. Circulation and fluxes in the North Atlantic between Greenland and Ireland. J. Phys. Oceanogr. 27, 1420-1435.

Beaird, N.L., Rhines, P.B., Eriksen, C.C., 2013. Overflow waters at the Iceland-Faroe Ridge observed in multiyear Seaglider surveys. J. Phys. Oceanogr. 43 (11) 2334-2351, http://dx.doi.org/10.1175/JPO-D-13-029.1.

Borenäs, K.M., Lundberg, P.A., 1988. On the deep-water flow through the Faroe Bank Channel. J. Geophys. Res. 93, 1281-1292.

Bower, A.S., Le Cann, B., Rossby, T., Zenk, W., Gould, J., Speer, K., Richardson, P.L. Prater, M.D., Zhang, H.-M., 2002. Directly measured mid-depth circulation in the northeastern North Atlantic Ocean. Nature 419, 603-607.

Bower, A.S., von Appen, W.-J., 2008. Interannual variability in the pathways of the North Atlantic current over the Mid-Atlantic Ridge and the impact of topography. J. Phys. Oceanogr. 38 (1), 104-120, http://dx.doi.org/10.1175/ 2007JPO3686.1.

Bower, A.S., Lozier, M.S., Gary, S.F., Böning, C.W., 2009. Interior pathways of the North Atlantic meridional overturning circulation. Nature 459 (14), 243-248, http://dx.doi.org/10.1038/nature07979.

Dietrich, G., 1956. Überströmung des Island-Färöer-Rückens in Bodennähe nach Beobachtungen mit dem Forschungsschiff "Anton Dohrn" 1955/56. Dtsch. Hydrogr. Z. 9 (2), 78-90.

Dooley, H.D., Meincke, J., 1981. Circulation and water masses in the Faroese Channels during Overflow '73. Dtsch. Hydrogr. Z. 34, 41-55. 
Fer, I., Voet, G., Seim, K.S., Rudels, B., Latarius, K., 2010. Intensive mixing of the Faroe Bank Channel overflow. Geophys. Res. Lett. 37, L02604, http://dx.doi.org/ 10.1029/2009GL041924.

Fischer, J., Schott, F.A., Dengler, M., 2004. Boundary Circulation at the exit of the Labrador Sea. J. Phys. Oceanogr. 34, 1548-1570.

Fischer, J., Visbeck, M., Zantopp, R., Nunes, N., 2010. Interannual to decadal variability of outflow from the Labrador Sea. Geophys. Res. Lett. 37, L24610, http://dx.doi.org/10.1029/2010GL045321(5pp.).

Fleischmann, U., Hildebrandt, H., Putzka, A., Bayer, R., 2001. Transport of newly ventilated deep water from the Iceland Basin to the Westeuropean Basin. Deep Sea Research Part I 48 (8), 1793-1819.

Hakkinen, S., Rhines, P.B., 2009. Shifting surface currents in the northern North Atlantic Ocean. J. Geophys. Res. 114, C04005, http://dx.doi.org/10.1029/ 2008JC004883.

Hansen, B., Østerhus, S., 2000. North Atlantic-Nordic Seas exchanges. Prog. Oceanogr. 45, 109-208.

Hansen, B., Østerhus, S., 2007. Faroe Bank Channel overflow 1995-2005. Prog. Oceanogr. 75, 817-856.

Harvey, A., Theodorou, A., 1986. The circulation of Norwegian Sea overflow water in the eastern North Atlantic. Oceanol. Acta 9 (4), 393-401.

Helland-Hansen, B., Nansen, F., 1909. The Norwegian Sea: Its Physical Oceanography Based Upon the Norwegian Researchers 1900-1904. Report on Norwegian Fishery and Marine Investigations. vol. 2, part 1.2. Bergen. pp. 1-390.

Hermann, F., 1967. The $T-S$ diagram analysis of the water masses over the IcelandFaroe Ridge and in the Faroe Bank Channel (Overflow '60). Rapports et Proce`sVerbaux des Re'unions du Conseil International pour l'Exploration de la Mer. vol. 157. pp. 139-149.

Johns, W.E., Watts, D.R., 1986. Time scales and structure of topographic Rossby waves and meanders in the deep Gulf Stream. J. Mar. Res. 44, 267-290.

Käse, R.H., Girton, J.B., Sanford, T.B., 2003. Structure and variability of the Denmark Strait Overflow: model and observations. J. Geophys. Res. 108, 3181, http://dx. doi.org/10.1029/2002JC001548(15pp.).

Lankhorst, M., Zenk, W., 2006. Lagrangian observations of the middepth and Deep Velocity Fields of the Northeastern Atlantic Ocean. J. Phys. Oceanogr. 36, 43-63, http://dx.doi.org/10.1175/JPO2869.1.

Lozier, M.S., Roussenov, V., Mark, S., Reed, C., Williams, R.G., 2010. Opposing decadal changes for the North Atlantic meridional overturning circulation. Nat. Geosci. 3, $728-734$.

Krauss, W., 1995. Currents and mixing in the Irminger Sea and in the Iceland Basin. J. Geophys. Res. 100 (C6), 10851-10871, http://dx.doi.org/10.1029/95JC00423.

Machín, F., Send, U., Zenk, W., 2006. Intercomparing drifts from eddy-resolving and cycling floats in the deep western boundary current along the Mid-Atlanic Ridge. Sci. Mar. 70 (1), 1-8, http://dx.doi.org/10.3989/scimar.2006.70n11.

Mauritzen, C., 1996a. Production of the dense overflow waters feeding the North Atlantic across the Greenland-Scotland Ridge. Part 1. Evidence for a revised circulation scheme. Deep-Sea Res. I 43 (6), 769-806.

Mauritzen, C., 1996b. Production of the dense overflow waters feeding the North Atlantic across the Greenland-Scotland Ridge. Part 2. An inverse model. DeepSea Res. I 43 (6), 807-835.

Mauritzen, C., Price, J., Sanford, T., Torres, D., 2005. Circulation and mixing in the Faroese Channels. Deep-Sea Res. I 52, 883-913.

Olsen, S.M., Hansen, B., Quadfasel, D., Østerhus, S., 2008. Observed and modeled stability of overflow across the Greenland-Scotland ridge. Nature 455, 519-523, http://dx.doi.org/10.1038/nature07302.

Østerhus, S., Hansen, B., Kristiansen, R., Lundberg, P., 1999. The Overflow through the Faroe Bank Channel. Int. WOCE Newslett. 35, 35-37.

Pickart, R.S., Watts, D.R., 1990. Deep Western Boundary Current variability at Cape Hatteras. J. Mar, Res. 48, 765-791.
Read, J.F., Pollard, R.T., Miller, P.I., Dale, A.C., 2009. Circulation and variability of the North Atlantic Current in the vicinity of the Mid-Atlantic Ridge. Deep-Sea Res. 57, 307-318.

Rhines, P., 1970. Edge, bottom, and Rossby waves in a rotating stratified fluid. Geophys. Fluid Dyn. 1 (3-4), 273-302, http://dx.doi.org/10.1080/03091927009365776.

Rydberg, L., 1980. Rotating hydraulics in deep-water channel flow. Tellus 32, 77-89.

Søiland, H., Budgella, W.P., Knutsen, Ø., 2008. The physical oceanographic conditions along the Mid-Atlantic Ridge north of the Azores in June-July 2004. DeepSea Res. II 55, 29-44.

Sætre, R., 1967. Report on the Norwegian Investigations in the Faeroe Channel 1964-65. NATO Subcommittee on Oceanographic Research Technical Report 38. 27pp.

Sarafanov, A., Falina, A., Mercier, H., Sokov, A., Lherminier, P., Gourcuff, C., Gladyshev, S. Gaillard, F., Daniault, N., 2012. Mean full-depth summer circulation and transports at the northern periphery of the Atlantic Ocean in the 2000s. J. Geophys. Res. 117, C01014, http://dx.doi.org/10.1029/2011JC007572.

Saunders, P.M., 1990. Cold outflow from the Faroe Bank Channel. J. Phys. Oceanogr. $20,28-43$

Saunders, P.M., 1992. Combining hydrographic and shipborne ADCP measurements. Deep-Sea Res. 39, 1417-1427.

Saunders, P.M., 1994. The flux of overflow water through the Charlie-Gibbs Fracture Zone. J. Geophys. Res. 99 (C6), 12343-12355.

Saunders, P.M., 1996. The flux of dense cold overflow water southeast of Iceland. J. Phys. Oceanogr. 26, 85-95.

Saunders, P.M., 2001. The dense northern overflows. In: Siedler, G., Church, J., Gould, J. (Eds.), Ocean Circulation and Climate. Academic Press, San Diego, pp. 401-417.

Schott, F., Stramma, L., Fischer, J., 1999. Interaction of the North Atlantic Current with the deep Charlie-Gibbs Fracture Zone throughflow. Geophys. Res. Lett. 26, 369-372.

Shor, A., Lonsdale, P., Hollister, C.D., Spencer, D., 1980. Charlie-Gibbs fracture zone: bottom-water transport and its geological effects. Deep-Sea Res. 27A, 325-345.

Steele, J.H., Barrett, J.R., Worthington, L.V., 1962. Deep currents south of Iceland. Deep-Sea Res. 9, 465-474.

Ulrich, J., 1960. Zur Topographie des Reykjanes-Rücken. Kiel. Meeresforsch. 16, 155-163.

van Aken, H.M., 1995. Mean currents and current variability in the Iceland Basin. Neth. J. Sea Res. 33, 135-145.

van Aken, H.M., Becker, G., 1996. Hydrography and through-flow in the northeastern North Atlantic Ocean: the NANSEN project. Prog. Oceanogr. 38, 297-346.

Worthington, L.V., Volkmann, G.H., 1965. The volume transport of the Norwegian Sea overflow water in the North Atlantic. Deep-Sea Res. 12, 667-676.

Worthington, L.V., 1976. On the North Atlantic Circulation. Johns Hopkins University Press, Baltimore, ISBN: 0801817420 p. 110.

Xu, X., Schmitz Jr., W.J., Hurlburt, H.E., Hogan, P.J., Chassignet, E.P., 2010. Transport of Nordic Seas overflow water into and within the Irminger Sea: an eddyresolving simulation and observations. J. Geophys. Res. 115, C12048, http://dx. doi.org/10.1029/2010JC006351.

Yashayaev, I., Bersch, M., van Aken, H.M., 2007. Spreading of the Labrador Sea Water to the Irminger and Iceland basins. Geophys. Res. Lett. 34, L1060, http: //dx.doi.org/10.1029/2006GL028999.

Zenk, W., Afghan, J.D., Bannert, B., Bleischwitz, M., Bulsiewicz, K., Cannaby, H., Csernok, T., Dombrowski, U., Friis, K., Fürhaupter, K., Greinert, J., Hauser, J., Karl, G., Lorbacher, K., Lüger, H., Malien, F., Marzeion, B., Müller, T., Niehus, G., Nielsen, M., Ochsenhirt, W.-T., Schafstall, J., Steinfeldt, R., Steinhoff, T., 2002. North Atlantic 2001, Cruise No. 50, Leg 4, 16 July-12 August 2001. METEORBerichte, Universität Hamburg. vol. 02-2. 38pp.

Zenk, W. 2008. Abyssal and contour currents. In: Rebesco, M., Camerlenghi, A (Eds.), Developments in Sedimentology, Contourites0070-4571vol. 60. Elsevier, Amsterdam, ISBN: 9780444529985, pp. 37-57. 